\title{
ZWIĄZKI TRADYCYJNEJ MUZYKI WOKALNEJ WOŁOCHÓW MIĘDZY KARPATAMI A BAŁKANAMI W KONTEKŚCIE HISTORYCZNYCH MIGRACJI WOŁOSKICH*
}

\author{
JUSTYNA CZĄSTKA-KŁAPYTA
}

\begin{abstract}
The links between traditional vocal music of the Vlachs from the Carpathian and the Balkan regions in the context of historical migrations of the Vlachs

The musical culture of the Aromanians, and other Wallachian-origin groups, was constantly subjected to acculturation and dynamic adaptation. These groups have preserved certain timeless, circulating musical constructs most likely influencing the architecture of the song melody, performance style and music-making patterns, which can be considered as a common idiom of the Wallachian vocal tradition. The common features of the Balkan (Aromanian) and Carpathian (Wallachian) vocal heritage are: natural harmonic hearing expressed in the tendency to sing without instrumental accompaniment, or with its participation in a heterophonic form. Polyphonic singing forms are characterized by a vocal hierarchy combined with a sensitivity to the acoustics of sound, which manifests itself in specific performance manners (slow pace, performance freedom, long breathing phrases, glissanding, etc.).

The Wallachian idiom of inter-voice chords is defined by the intervals of fourths, fifths, octaves and dissonances especially seconds. The greatest similarities are especially visible between the vocal repertoire of Carpathian Ruthenians and Aromanians, also in relation to the scale, the morphology of the song melody (e. g. tetrachordal and pentachordal structure of phrases, the primary meaning of the fourth, the tendency to descendental phrases) and to descendental rhythmic punctuated and inversely scored.

The common Wallachian musical heritage also includes musical instruments such as: fujara, duda / gajda, trembita, dwojnica, which music scale and melody contributed to the unification of diverse and geographically distant vocal dialects along with their ritual-magic background related with pastoral lifestyle.

Singing for voices is considered as a basic feature of ethnic identity, and as a tool of communication and social integration within the present-day Wallachian ethnoses. The survival of the unique polyphonic singing practice may be related to migratory nature of Wallachian lifestyle as well as relative cultural and geographical isolationism of mountain areas together with the scattered nature of the Wallachian settlement. Differences between the Carpathian and Balkan polyphony may have been related to the crushing of archaic polyphonic forms (drones), which in Carpathians have survived mainly on the instrumental grounds. The performance manners and the archaic repertoire associated with drones were influenced by East Slavic variation heterophony, and then medieval polyphonic technique (discantus) disseminated in Catholic and Orthodox churches during the Wallachian migration period. Finally, the major-minor harmonics, contributed to the disappearance of polyphonic structures and the flattening of Wallachian vocal idioms.
\end{abstract}

StReszCZenie. Kultura muzyczna Aromanów, potem zrutenizowanych i w końcu spolonizowanych grup wołoskich ulegała procesom akulturacji, adaptacji i przetwarzania. Prawdopodobnie w świadomości grupowej tego etnosu przetrwały pewne ponadczasowe, obiegowe konstrukty muzyczne, które wpływały na melodykę pieśniową, stylistykę wykonawczą i wzory muzykowania. Można je uznać za wspólny idiom dla zróżnicowanej wołoskiej tradycji wokalnej. Za wspólne cechy bałkańskiego (aromańskiego) i karpackiego (wołoskiego) dziedzictwa wokalnego uznaje się: przyrodzony słuch harmoniczny, wyrażany w skłonności do śpiewania na głosy bez towarzyszenia instrumentalnego, bądź z jego udziałem w formie heterofonicznej. Wielogłosowe formy śpiewu cechuje hierarchizm głosowy połączony z wrażliwością na akustykę brzmienia, która przejawia się w specyficznych manierach wykonawczych (wolne tempo, swoboda wykonawcza, długie frazy oddechowe, glissandowanie

* Artykuł powstał w ramach projektu NPRH Wolosi w europejskiej i polskiej przestrzeni kulturowej. Migracje - osadnictwo - dziedzictwo kulturowe (Projekt nr 0604/NPRH3/H12/82/2014). 
i inne). Wołoski idiom współbrzmień międzygłosowych określają interwały kwarty, kwinty, oktawy i dysonanse - zwłaszcza sekundy. Największe podobieństwa zaznaczają się zwłaszcza pomiędzy repertuarem wokalnym karpackich Rusinów i Aromanów także w odniesieniu do podłoża skalowego, morfologii melodyki pieśniowej (np. tetrachordalna i pentachordalna budowa fraz, prymarne znaczenie kwarty, skłonność do descendentalnych fraz) oraz do descendentalnej rytmiki punktowanej i odwrotnie punktowanej. Do wspólnego wołoskiego dziedzictwa muzycznego zaliczają się także instrumenty muzyczne jak: fujara, duda/gajda, trembita, dwojnica, których podłoże skalowe i melodyka przyczyniały się do ujednolicania zróżnicowanych i odległych geograficznie wokalnych dialektów wołoskich wraz z całym rytualno-magicznym podłożem jeszcze do niedawna zrośniętym z pasterskim trybem życia. Także we wszystkich współczesnych etnosach wołoskich, jak i w tych, które uważają się za spadkobierców tej tradycji, śpiew na głosy jest traktowany jako wyróżnik tożsamości etnicznej, podstawowe narzędzie komunikacji i integracji społecznej. Przetrwanie tej unikalnej na skalę zarówno Karpat jak i Bałkanów wielogłosowej praktyki śpiewu może być odpowiedzią na poczucie wyizolowania i migracyjnego charakteru życia Wołochów. Innymi przyczynami mogą być stosunkowy izolacjonizm kulturowy i geograficzny obszarów górskich, a także rozproszony i górski charakter wołoskiego osadnictwa. Na odczuwaną audytywnie odrębność wielogłosu karpackiego od bałkańskiego mogły mieć wpływ zarówno procesy kruszenia archaicznych form wielogłosu (dron), przetrwałych bardziej na gruncie instrumentalnym, także manier wykonawczych i związanego z nimi archaicznego repertuaru, jak i późniejsze nawarstwienia związane z wpływami wschodniosłowiańskiej heterofonii wariacyjnej, a następnie średniowiecznej techniki wielogłosowej (discantus) rozpowszechnianej w świątyniach katolickich i prawosławnych w okresie migracji wołoskich i w ostateczności wpływów harmoniki dur-moll, która przyczyniła się do zaniku polifonicznych struktur myślenia i spłaszczenia wołoskiej idiomatyki wokalnej.

Keywords: ethnomusicology, polifony of dron, heterophony, Wallachian instruments, Hutsulschyna, Vlachs, oral musical tradition, Aromanian, acculturation, melismatic style, tetrachord, Wallachian scale

Słowa kluczowe: etnomuzykologia, polifonia dronu, heterofonia, instrumenty wołoskie, Huculszczyzna, Wołosi, oralna tradycja muzyczna, arumuński, akulturacja, styl melizmatyczny, tetrachord, skala wołoska

Autorka: Justyna Cząstka-Kłapyta, Uniwersytet Jagielloński, Instytut Geografii i Gospodarki Przestrzennej, Gronostajowa 7, 30-387 Kraków, hucul.klapytki@gmail.com, ORCID iD: https://orcid.org/0000-0001-5548-8881

Balcanica Posnaniensia. Acta et studia, XXVIII/1, Poznań 2021, Wydawnictwo Wydziału Historii UAM, pp. 321-362

ISBN 978-83-66355-68-2, ISSN 0239-4278. Polish text with summaries in English and Polish

doi.org/10.14746/bp.2021.28.14

Kultura karpacka z całym swoim bogactwem form duchowych (muzyki i wierzeń) tworzy kulturowy kręgosłup Europy, w którym przetrwały na skutek stosunkowo długo trwającej izolacji typowej dla obszarów górskich, oprócz cennych reliktów należących do kultury materialnej i duchowej, także wchodzące w obręb tej ostatniej archaiczne elementy ludowej tradycji muzycznej. Poruszone w tym artykule kwestie ogólnej charakterystyki muzycznych tradycji etnosu wołoskiego wiążą się z jego zawiłymi dziejami historycznymi, najpierw na terytorium Bałkanów, następnie głównie na górskich obszarach Europy Środkowej, gdzie zasymilował się on z większościowymi społecznościami etnicznymi ${ }^{1}$. Przebieg tych migracji, ich skomplikowany

${ }^{1}$ P. Kłapyta, Woloskie osadnictwo w Karpatach w aspekcie historyczno-geograficznym, [w:] Kultura pasterska tuku Karpat i jej oddziatywanie na kulturę Babiogórców: materiaty z konferencji naukowej 
charakter i długowiekowy proces przesądził o wytworzeniu się zróżnicowanych pod względem kulturowym obszarów muzycznego dziedzictwa wołoskiego, co szczególnie fascynuje, bo kształtowanego niezależnie od granic i podziałów państwowych. Obszary te pokrywają się ze szlakiem historycznych migracji etnosu wołoskiego, od Grecji, przez Albanię, Serbię, Macedonię, górskie regiony Bułgarii, Rumunii², Ukrainy (Huculszczyzna) ${ }^{3}$, Polski ${ }^{4}$, Słowacji, jak i z regionami współczesnego zamieszkania autochtonicznych wspólnot wołoskich zwanych Arumunami, Aromanami, Vlachami. Określenie „Wołoch” jest późniejsze i wiąże się z tradycją wschodniosłowiańską ${ }^{5}$ Arumuni stanowią obecnie stosunkowo liczną grupę (0,5 miliona) o wykrystalizowanym poczuciu odrębności narodowej, która zamieszkuje wyspowo obszar rozciągający się od środkowej Grecji (Tesalia) poprzez górskie tereny Epiru i Pindosu, gdzie zamieszkują Gramostianie i Pindianie, południową Albanię, zasiedloną przez Farszerotów, Macedonię aż po południowo-wschodnią Serbię, Bułgarię i południową Rumunię (okolice Banatu, terytorium Dobrudży), gdzie trafili w trzech falach: w okresie Imperium Osmańskiego, z końcem wieku XIX i w największym stopniu w latach dwudziestych i trzydziestych XX wieku'. W ten sposób w Rumunii znaleźli się m.in. Gramostianie z północnej Grecji, Farszeroci z obszarów wschodniej Albanii i zachodniej Macedonii ${ }^{7}$. Istotny wpływ na charakter i rozwój kultury muzycznej tego etnosu miał też fakt przynależenia Wołochów za czasów panowania Turków do jednego organizmu państwowego, który później uległ rozpadowi na

zorganizowanej przez Babiogórskie Centrum Kultury w Zawoi z okazji 30. „Babiogórskiej Jesieni”, 19 września 2014, red. U. Janicka-Krzywda, Kraków 2014, s. 9.

2 W Rumuni osadnictwo z żywiołem wołoskim występowało na terenie Zakarpacia, Mołdawii i Siedmiogrodu, w którym istniało siedem okręgów wołoskich: Fagăraş, Maramureş, Deva, Haţeg, Huynad, Lugoş, Banat Temesvárski (Timişoara); I. Czamańska, Wołosi - strażnicy gór, [w:] Kalendarz 2014. Informacje pasterskie od owcy plus do Redyku Karpackiego 2013, Koniaków 2014, s. 17-33, s. 29.

${ }^{3}$ W średniowieczu tereny objęte kolonizacją wołoską znajdowały się na Rusi Czerwonej, która należała do Rzeczpospolitej i objęły w górach regiony Huculszczyzny i Bojkowszczyzny.

4 Według Grzegorza Jawora zachodnia granica etniczna osadnictwa wołoskiego z elementami rusińsko-wołoskimi na terenie Karpat polskich, przebiega na linii doliny Dunajca, od Rusi Szlachtowskiej przez wschodnie zbocza Gorców do Ochotnicy. Biorąc pod uwagę to kryterium kontynuacja tej granicy po obecnej słowackiej stronie dowiązuje do zasięgu osad ruskich na słowackim Spiszu położonych na terenie Gór Lewockich na Spiszu i w Sariszu (Jakubiany, Repasze). Najdalej na zachód wysuniętą wsią etnicznie rusińsko-wołoską jest Osturnia. Pozostałe wsie na terenie Podhala, Orawy, Beskidu Śląskiego, Żywieckiego, Starostwa Lanckorońskiego, Kisuc, Śląska Cieszyńskiego tworzone były głównie przez osadników polskich, słowackich, czeskich, którzy wyznawali katolicyzm i protestantyzm. Prawo wołoskie na którym zakładano wsie w tych regionach było modyfikacją prawa niemieckiego do warunków górskich: G. Jawor, La colonisation valaque sur les versants nord des Carpates pendant le Petit Âge Glaciaire (aux XVe et XVIe siècles), „Balcanica Posnaniensia. Acta et studia” 2018, t. 25, s. 251-268.

${ }^{5}$ P. Kłapyta, Wołoskie osadnictwo, s. 12. Pojęcie to używam w tytule artykułu jako synonim ludności pasterskiej, zamieszkującej regiony zasiedlone przez etnos wołoski (w przypadku podjętych tu rozważań - Karpaty i Polesie).

${ }^{6}$ E. Nowicka, Nasz język rozumieją aniołowie. Arumuni we wspótczesnym świecie, Kraków 2011, s. $72-78$.

${ }^{7}$ Ibidem, s. 77. 
skutek czego granice nowych państw rozdzieliły od siebie różne grupy wołoskie ${ }^{8}$. Nowa sytuacja mogła generować sprzeczne tendencje rozwojowe kultury muzycznej Wołochów. Z jednej strony musiała wywołać poczucie lęku związanego z wyizolowaniem, rozbiciem społeczno-rodowych więzi, które wyzwalały potrzebę podtrzymywania i wzmacniania własnej tożsamości etnicznej, której jednym z ważniejszych wyznaczników jest i dzisiaj tradycja muzyczna ${ }^{9}$. Z drugiej zaś, społeczność ta odczuwała na każdym etapie historycznej wędrówki potrzebę przynależności do większego organizmu państwowego i czyniła to mniej lub bardziej świadomie przez procesy akulturacyjne. Fakty te przejawiają się do dziś zarówno w zróżnicowanym charakterze tradycji muzycznej tego etnosu, jak i ukrytych w niej tendencjach konserwatorskich, które są jednym z wyróżników pasterskich społeczności, a zwłaszcza grup migracyjnych dążących do zachowania własnej autonomii kulturowej. Wielokulturowe oblicze tradycji wołoskiej wynika więc z jego kształtowania na pograniczu kulturowym, czyli w procesie wielowiekowego, stałego lub tylko okresowego sąsiedztwa z innymi etnosami; z Grekami, Albańczykami, Turkami, Serbami, Macedończykami, Bułgarami, Rusinami, Słowakami, Polakami i Węgrami oraz wielu innymi ${ }^{10}$. Każdy z tych etnosów miał mniej lub bardziej widoczny wpływ kulturowy na charakter etnosu wołoskiego". Także odrębność muzyki ludowej Karpat na tle innych polskich regionów wynika $\mathrm{z}$ usytuowania regionu karpackiego na pograniczu kulturowym, gdzie przenikanie różnych elementów z sąsiednich kultur narodowych i etnicznych jest zjawiskiem naturalnym ${ }^{11}$. Karpaty to jednak region, który oprócz stwierdzonych jednoczących go elementów wołoskich (gospodarka pasterska, nazewnictwo), cechuje się dużym wewnętrznym zróżnicowaniem kulturowym. W odniesieniu do regionu południowych Bałkanów muzyczną mozaikowość kulturową stwierdza Ioan Caranica wydzielając trzy aromańskie (arumuńskie) regiony muzyczne:

- region Arumunów Północnych zamieszkujących góry Gramos z przedłużeniem do gór Pindos,

- region Arumunów Południowych, czyli Arumunów z Epiru - w tę grupę wchodzą także Arumuni z okręgu Verii pochodzący również z Epiru,

- region Ferszerotów (pasterzy nomadów z Albanii) ${ }^{12}$.

Muzyka Aromanów, potem grup wołoskich ulegała i nadal ulega nieustannym procesom adaptacji i przetwarzania $\mathrm{w}$ zgodzie $\mathrm{z}$ własnymi i właściwymi dla grup

\footnotetext{
8 P. Kłapyta, Woloskie osadnictwo, s. 11.

9 J. Jordania, Who asked the first questions? The Origins of human choral singing, intelligence, language and speech, Logos 2006, 210-229.

${ }^{10}$ E. Kocój, Dziedzictwo bez dziedziców? Religijne i materialne dziedzictwo kulturowe mniejszości pochodzenia woloskiego $w$ Europie w kontekście interdyscyplinarnych badań, projektu (przyczynek do tematu), „Zarządzanie w Kulturze” 2015, t. 16, nr 2, s. 143.

11 A. Chybiński, Karol Szymanowski a Podhale, „Wierchy” 1938, nr 16, s. 24.

12 Według tego badacza tylko ta grupa stosuje polifonię drona; I. Caranica, 130 Melodii Populare Aromâneş̧ti, Bucureşti 1937, s. 7.
} 
większościowych obiegowymi wzorami muzykowania. Krążące w świadomości grupowej wzory muzyczne mogą odnosić się do: repertuaru pieśniowego, tanecznego, instrumentalnego, wykonawstwa, interpretacji, skal, sposobu klasyfikacji repertuaru, a nawet gustów muzycznych. Procesy te doprowadziły w konsekwencji do daleko posuniętej muzycznej akulturacji, niekiedy rozbicia autochtonicznych form muzykowania, na które złożyło się także rozproszenie ludności wołoskiej, grupowych więzi przez brak własnej państwowości i prowadzenie transhumancyjnego sposobu gospodarowania. Do dziś znane jest wśród uświadomionych regionalistów karpackich rozpowszechnione bardziej w formie mitu niż rzeczywistych opartych na rzetelnych badaniach naukowych faktów przekonanie, o istnieniu śladów wołoskich w folklorze muzycznym Karpat. Problem muzycznego dziedzictwa wołoskiego w Karpatach należy do tematów przez lata pomijanych milczeniem w oficjalnym dyskursie narodowym, nie wspominając już o całkowitym braku prac o charakterze międzynarodowym. Pomimo to, tematyka ta od lat budzi zainteresowanie wśród wielu badaczy i regionalistów. Największy wkład w badanie związków między karpacką i ogólną bałkańską polifonią mieli w latach 90. XX wieku Alicja i Oskar Elschekowie ${ }^{13}$. Na gruncie polskim pojawił się tylko jeden artykuł o charakterze przyczynkowym ${ }^{14}$. Ten stan rzeczy wynika być może stąd - jak pisze Ewa Kocój, że problematyka wołoska zalicza się do tzw. „obszaru trudnego dziedzictwa, rodzącego napięcia i konflikty, bowiem obiekty materialne i duchowe do niego należące mogą mieć dla odbiorców z rozmaitych grup społecznych różne, często przeciwstawne znaczenie" ${ }^{15}$. Do tego można dodać zawikłaną przeszłość historyczną niektórych etnosów karpackich - Rusinów (akcja Wisła 1947) i wynikające m.in. $z$ tego długo trwające zaniechanie badań nad ich tradycją muzyczną i to ze strony zarówno polskich, ukraińskich, rumuńskich, jak i słowackich badaczy. Podobnie była nie rozważana przez etnomuzykologów kwestia związków muzyki Karpat, w tym muzyki etnosu rusińskiego z muzyką współczesnych etnosów wołoskich. Jednak to właśnie pozostawione na marginesie muzyczne dziedzictwo Karpatorusinów (Huculi, Bojkowie, Łemkowie, słowaccy Rusnacy) może być kluczem do rozwiązania problematyki wkładu bałkańskich elementów kultury muzycznej do tradycji Karpat. Wynika to po pierwsze z największego nawarstwienia wśród Karpatorusinów elementu etnicznie wołoskiego ${ }^{16}$, po drugie przetrwania w muzyce tego etnosu wielu niespotykanych, albo już dawno zanikłych w innych regionach Karpat archaizmów ${ }^{17}$ i po trzecie, ze względu na fakt, że etnos ten zajmował największą powierzchnię w Karpatach i mógł przez to znacząco oddziaływać na sąsiednie gru-

13 A. O. Elschekowie, Stratigraphische Probleme der Volksmusik in den Karpaten und auf dem Balkan, Bratislava 1981.

14 J. Cząstka-Kłapyta, Wpływy wołoskie w folklorze muzycznym Karpat ze szczególnym uwzględnieniem rusińskiej wsi Osturnia - przyczynek do rozważań, [w:] Wołoskie dziedzictwo Karpat, Czeski Cieszyn 2007, s. 51-68.

15 E. Kocój, Dziedzictwo bez dziedziców?, s. 139.

16 J. Cząstka-Kłapyta, Wpływy wołoskie w folklorze muzycznym Karpat.

17 K. Bičanová, Piesňovy repertoár Rusinov na hornym Spiši, „Slovenská hudba” 2000, t. 26, s. 302 . 
py etniczne jak np. na górali podhalańskich i spiskich (od strony Osturni) ${ }^{18}$ zwłaszcza z uwagi na dzielenie z nimi wspólnych terenów wypasowych w Tatrach i znaczącą na Podtatrzu wysoką pozycję osturniańskich baców ${ }^{19}$. Obiektywny ogląd problematyki wołoskiej może obciążać „,mit Podhala” jako regionu postrzeganego, zarówno w naukowym, jak i zwłaszcza komercyjnym oraz ostatnio też wewnątrzkulturowym obiegu za reprezentatywny dla polskich Karpat i sięgający swoimi korzeniami bezpośrednio do tradycji wołoskich ${ }^{20}$. Kwestie zasięgu melodii i pieśni górali podhalańskich na północ i południe od regionu Podhala badał Adolf Chybiński ${ }^{21}$. Ich zasięg na północ okazał się „bardzo krótki”, a na południe rozległy sięgający Słowacji, Moraw, Węgier, Huculszczyzny, Łemkowszczyzny, Wołoszczyzny, Rumunii, Siedmiogrodu, Jugosławii, który według Jerzego Przerembskiego może być wynikiem migracji romskich, zarobkowych, zbójnickich ${ }^{22}$. Jednak o możliwościach wołoskich wpływów nic nie wspomina i wyraźnie zalicza ten wątek do problemów trudnych do jednoznacznego określenia. Jest zdania, że na Podhalu idiomatyka wołoska rozumiana jako skłonność do melizmatyki, skali wołoskiej (cygańskiej) i pięciomiaru ${ }^{23}$ nie występuje. Stwierdza też, ,że na Podhalu gra się na dudach czterogłosowych, nie zaś dwugłosowych, jak w sąsiednich polskich regionach (Beskid Żywiecki i Śląski, Orawa, Suskie, Babiogórskie), a po drugiej stronie Tatr używane są dudy trzygłosowe, rodzaj najbardziej rozpowszechniony w Słowacji, a także na Huculszczyźnie"24. Wpływy wołoskie w muzyce Karpat (polskich) podkreślał z kolei Jan Stęszewski, chociaż nigdy nie poświęcił temu zagadnieniu większej uwagi pisząc m.in; „Ze Słowakami, Hucułami, Węgrami i ludami bałkańskimi, południowopolski folklor muzyczny posiada wspólne lub podobne instrumenty, descendentalne rytmy punktowane, formy wielogłosowości, niektóre tańce: faktycznie mogą być śladem migracji wołoskiej, która niosła z południa określony typ kultury pasterskiej"25. Cenny wkład w poznanie muzyki karpacko-bałkańskiej mają prace Beli Bartoka - zasłużonego zwłaszcza dla węgierskiej etnografii muzycznej ${ }^{26}$. Bogatsze w odrębne opracowania tej problematyki są prace na temat muzyki bałkańskich Wołochów. Większość z tych zagranicznych prac skupia się na badaniu wielogłosowości (śpiew wieloczęściowy)

18 J. Cząstka-Kłapyta, Wpływy woloskie w folklorze muzycznym Karpat.

${ }^{19}$ I. Chałupecky, Dejiny Osturne, Kieżmark 2004, s. 149.

${ }^{20}$ E. Kocój, Dziedzictwo bez dziedziców?, s. 142.

${ }^{21}$ A. Chybiński, O źródtach i rozpowszechnieniu dwudziestu melodii ludowych na Skalnym Podhalu [w:] O polskiej muzyce ludowej, Warszawa 1961, s.113-143.

${ }_{22}$ Z. Przerembski, Muzyka ludowa po obu stronach Tatr, podobieństwa, zwiazki, różnice, kierunki oddziaływań, „Muzyka” 2018, z. 2, s. 47, za: A. Chybiński, O źródlach i rozpowszechnieniu, s. 141.

${ }^{23}$ Z. Przerembski powołuje się tu na moje wstępne wyniki badań nad muzyką Rusinów Osturniańskich w kontekście domniemanych wpływów wołoskich; J. Cząstka, Wpływy wołoskie w folklorze muzycznym Karpat.

${ }^{24}$ Z. Przerembski, Muzyka ludowa po obu stronach Tatr, s. 55.

25 J. Stęszewski, Muzyka ludowa, [w:] Etnografia Polski. Przemiany kultury ludowej, t. 2, Kraków 1974, s. 264.

${ }^{26}$ B. Bartok, Hudobnowedny zbornik - casopis Slovenskej Akademie Vied., Bratislava 1954; idem, Slovenské l'udové piesne, Bratislava 1970. 
głównie albańskiej polifonii, jednak bez wnikania w morfologię wokalnej dialektyki Aromanów (np. Stockmann ${ }^{27}$ ). Kilka publikacji publikowanych w Grecji na temat muzyki aromańskiej (m.in. Padiotis ${ }^{28}$ ) to zbiory tekstów pozbawionych analiz etnomuzykologicznych. Pierwsze prace poświęcone śpiewowi wieloczęściowemu greckich Aromanów pojawiają się w artykułach Katsanevakiego ${ }^{29}$ i Nitsiakosa ${ }^{30}$. Wśród badaczy zajmujących się regionem Rumunii należy wymienić kilka reprezentatywnych nazwisk: Georgea Marcu ${ }^{31}$, Nikolaia Kaufmana ${ }^{32}$, Constantina Brăiloiu, Emilii Comişel, Tatiany Găluşcă-Cîrşmariu ${ }^{33}$. Wielogłos bułgarski analizował Nicolaus Kaufman. Niniejszy artykuł podejmuje zatem kolejną próbę szerzej zakrojonych badań nad problemem odszukania śladów muzycznych związków zachodzących w muzyce wołoskiej między Karpatami a Bałkanami. Podstawą opracowania jest charakterystyka i porównanie niektórych aspektów wokalnej dialektyki etnosów wołoskich. Do analizy porównawczej wybrane zostały wybiórczo chronologicznie najstarsze pieśni z regionu Karpat (pasterskie, obrzędowe). Można je potencjalnie uznać za źródła do rozpoznania wołoskich substratów muzycznych poprzez ich analizę komparatystyczną z XX wiecznymi zapisami źródłowymi repertuaru wokalnego dziś żyjących grup wołoskich (Aromanów) oraz nagrań ich reliktowych form śpiewu. Kultura muzyczna Aromanów służy tu więc jako źródło, punkt odniesienia, eksperymentalna forma skamieliny do rozpoznania domniemanych wołoskich śladów muzycznych zaszczepionych w okresie „migracji wołoskich” wokalnej dialektyce etnosów karpackich, a zwłaszcza tych, gdzie mogła sięgać granica zasięgu zrutenizowanego etnosu wołoskiego ${ }^{34}$. Do analizy zostały wzięte pod uwagę kryteria związane ze stylistyką wykonawczą, ludową polifonią, cechami morfologicznymi melodii, jej budową formalną i podłożem tonalnym. Kwestie związków instrumentalnych traktuje tu bardzo powierzchownie ${ }^{35}$, a taneczne i pieśniowe pomijam ze względu na zbyt obszerną problematykę, która nasuwa konieczność prowadzenia odrębnych studiów. Na margi-

27 D. Stockmann, E. Stockmann, Die Vokale Bordun-Mehrstimmigkeit in Südalbanien, [w:] Les Colloques de Wégimont, IV 1958-1960, „Ethnomusicologie” 1964, t. 3, s. 85-135; D. Stockmann, W. Fiedler, E. Stockmann, Albanische Volksmusik, t. 1 (Gesänge der Çamen. Veröffentlichungen des Instituts für deutsche Volkskunde), Berlin 1965, ss. 302.

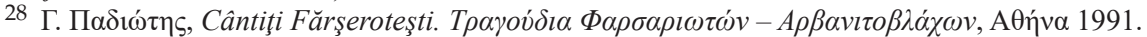

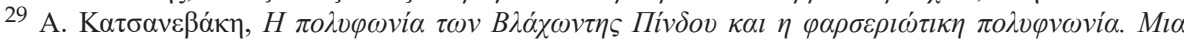

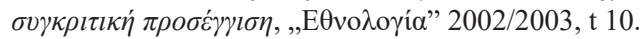

${ }^{30}$ V. Nitsiakos, C. Mantzos, Negotiating culture: political uses of polyphonic folk songs in Greece and Albania, [w:] Greece and the Balkans: identities, perceptions and cultural encounters since the Enlightenment, red. D. Tziovas, London 2003, s. 192-207.

${ }^{31} \mathrm{G}$. Marcu, Un sistem identic de execuţie polifonică a cîntecelor populare, întîlnit la unele popoare din Peninsula Balcanică, „Revista de Etnografie şi Folclor” 1968, nr 13, s. 545-554; idem, Folclor muzical Aromân. Bucureşti 1977.

${ }^{32}$ N. Kaufman, Cîntece aromâneşti din Satul Dorkovo, Raionul Velingrad, ,Revista de Etnografie şi Folclor" 1969, t. 14, nr 1, s. 69-75.

${ }^{33}$ C. Brăiloiu, E. Comişel, T. Găluşcă-Cîrşmariu, Folclor din Dobrogea, Bucureşti 1978.

${ }^{34}$ Patrz przypis 4.

35 Problematyce instrumentalnej poświęciłam uwagę w innych opracowaniach: J. Cząstka-Kłapyta, Funktion and genesis of "trombita" music instrument with special attencion to Huculschyna region 
nesie rozważań pozostawiam także zagadnienia genezy i źródeł zjawisk muzycznych (poza przytaczaniem poglądów już istniejących), gdyż problematyka wołoska oscyluje nieustannie wokół problemów pogranicza etnicznego, na którym przyporządkowanie etniczne konkretnych melodii, cech, syndromów pewnych zjawisk muzycznych jest niezwykle trudne, ponieważ granice języków nie pokrywają się z granicami występowania zjawisk muzycznych ${ }^{36}$.

\section{POLIFONIA DRONA}

Jednym z ważniejszych elementów wokalnej tradycji wołoskiej jest uwarunkowany regionalnymi odmianami śpiew wielogłosowy spotykany u niemal wszystkich etnosów wołoskich poza wyjątkiem Hucułów (Ukraina, Karpaty Wschodnie), gdzie dominuje śpiew monofoniczny pozostający w nierozerwalnej wręcz symbiozie z grą na instrumencie $\mathrm{w}$ formie towarzyszenia heterofonicznego ${ }^{37}$. Zbliżone formy monofonicznych i homofonicznych śpiewów $\mathrm{z}$ towarzyszeniem instrumentalnym (jak u Hucułów) występują w Rodopach (Bułgaria), gdzie obok wokalnych form jednogłosowych znane są też wielogłosowe formy śpiewu ${ }^{38}$. Śpiew jednogłosowy praktykują także Aromanie północni z gór Gramos i Pindos i południowi z Epiru i okręgu Verii. Z kolei w regionie Gramosty, Nevesca i Nevii spotkać można dwugłosowe formy śpiewu ${ }^{39}$. Zarówno śpiew jednogłosowy, czyli monodia i wielogłosowy (polifonia) rozumiany jako wypadkowa linearnego prowadzenia niezależnych linii głosowych mają starożytne korzenie. Śpiew monofoniczny pojawił się w Europie najprawdopodobniej wraz z migracjami ludów rozpowszechniających indoeuropejskie języki, a następnie z innymi migracjami ludności, które sprzyjały rozpowszechnianiu tradycji śpiewu typowego dla Azji Zachodniej. Starożytną proweniencję, wiązaną z osadnictwem indoeuropejskim ma również zachowana u Arumunów najstarsza w Europie technika wokalna - polifonia drona (ang. drone $)^{40}$ określana także przez et-

„Balcanica Poznaniensia. Acta et studia” 2016, t. 23, s. 187-196; idem, Oral tradition (music), culture and nature: the European heritage of sheep farming and pastoral life, Lubaczów 2011.

36 J. Stęszewski, Muzyka Ludowa, [w:] Etnografia Polski - przemiany kultury ludowej, Warszawa, t. 2, s. 246.

${ }^{37}$ I. Macijewski, Muzyczni instrumenty Huculiw, red. J. D. Kolesnyk, Winnycja 2012.

38 Można podać przykład jednej z pasterskich pieśni z Rodopów (Bułgaria) Rufinka bola legnala. Pieśń jest śpiewana z polifonicznym towarzyszeniem gajd. Melodia tej pieśni to wariant znanej na Huculszczyźnie spiwanky weselnej wykonywanej przy ubieraniu drzewka weselnego (derewca) - Sosnowenkie dereweczko, zapisanej przez S. Mierczyńskiego: Muzyka Huculszczyzny, red. Jan Stęszewski, Kraków 1965; Rufinka bolna legnala (Руфинка болна легнала), https://www.youtube.com/ watch?v=9QR2MUtTkqA [dostęp: 16.07.2021].

${ }^{39}$ I. Caranica, 130 Melodii Populare, s. 7.

$40 \mathrm{https} / / /$ en.wikipedia.org/wiki/Drone_(music) [dostęp: 16.07.2021]. Inne pieśni z regionu Rodopów: Old Bulgarian Wedding Folk Song - Moma se s Roda Proshtava, https://www.youtube.com/ watch?v=W9fPINoFjoo [dostęp: 16.07.2021]. 
nomuzykologów jako śpiew wieloczęściowy ${ }^{41}$. Systematyczne stosowanie dronów pochodzi najprawdopodobniej ze starożytnej muzyki instrumentalnej południowo-zachodniej Azji, skąd rozprzestrzeniło się na północ i zachód Europy, na wschód do Indii i na południe do Afryki ${ }^{42}$. Poza tradycją śpiewu, dron występuje w grze na instrumentach muzycznych używanych przez Aromanów i górali karpackich ${ }^{43}$; dudach/ gajdach, ftojerze z charakterystycznym burdonowym buczeniem w krtani (Huculszczyzna, Karpaty Wschodnie - Ukraina $)^{44}$, w zespołowej grze trembit, rogów, bądź trembit i rogów na (Huculszczyza) ${ }^{45}$. Na gruncie karpackim pokrewną technice drona jest stale powtarzana w różnych kombinacjach harmonicznych nuta basowa w charakterze burdonu, realizowana przez instrument smyczkowy - basy w zespołach instrumentalnych np. górali rusińskich (Bojkowie, Łemkowie), podhalańskich, czy pienińskich (Polska), gdzie u dwóch ostatnich przybiera wyraźniejsze schematy harmoniczno-kierunkowe stanowiąc bazę dla wybijającej się w ich tle zornamentowanej linii melodycznej instrumentu prowadzącego główną linię melodyczną (skrzypiec). Efekt „drona” może być realizowany także w jednej z części konstrukcyjnej instrumentu muzycznego, z której wydobywa się stały, nisko brzmiący dźwięk burdonowy np. bak w dudach podhalańskich, czy basok w dudach huculskich, czy w jednym z kanałów melodycznych podwójnych piszczałek (dwojnica). Na gruncie bałkańskiej polifonii wokalnej dron może być realizowany w dwojaki, symultaniczny sposób: monofoniczny lub harmoniczny. Jego istota polega na stałym, monotonnym powtarzaniu przez większość lub cały utwór stałego dźwięku (burdonu), lub pewnych struktur monofonicznych lub harmonicznych, które pojawiają się w różnych piętrach polifonicznej tekstury: najniższym, środkowym lub najwyższym. Każde z tych pięter tworzy specyficzne dwie, trzy, cztery lub nawet pięć struktur brzmieniowych. Efekt drona można uzyskać także poprzez przedłużanie usytuowanych na jednym poziomie dźwięków. Może być także pewną składową powtarzalną częścią pieśni, która jest

41 Na temat pojawienia się w Europie pierwszych nosicieli języków indoeuropejskich trwają nadal dyskusje, które umiejscawiają ich przybycie między trzecim a pierwszym tysiącleciem p. n.e; J. Jordania, Who asked the, s. 213, 215.

42 Ibidem.

43 J. Cząstka-Kłapyta, Oral tradition (music), culture and nature.

44 Towarzyszące fłojerze specyficzne „,burczenie w krtani” grającego, przypomina niezbędny element azjatyckich technik śpiewu kilkoma głosami znanych w Azji Środkowej (Chakasów, Baszkirów, Kazachów, Tuwińców). Instrument ten prezentuje najpierwotniejszy typ fujarek otwartych na obu jego końcach. Na Ukrainie i w Polsce występuje tylko w górskich regionach. W Rumuni znany jest ten instrument pod nazwą fluierul do cop, fluer, caval, na Węgrzech - furugla, furuglya, na Słowacji - pišcalka pastirska, w Bułgarii i Macedonii - kàval, a w Polsce odnotowana już jako instrument na wyginięciu tylko w okolicach Piwnicznej i na Podhalu - pod nazwą piszczałka postna lub fujera; J. Cząstka-Kłapyta, O uchwytnych zapożyczeniach i ich chronologii w tradycji muzycznej Hucułów, [w:] Huculszczyzna w badaniach młodych naukowców, red. M. Troll, A. Warchalska, Kraków 2011, s. 218.

45 Przed II wojną światową rozpowszechnione było inicjowanie pljesu (pląsu) przez jedną trembitę przy wtórze burdonowym rogów i pozostałych trembit. Obecnie w zespołowej grze na tych instrumentach główną melodię prowadzi trembita przy burdonowym wtórze pozostałych instrumentów (w odległości tercji wielkiej: J. Cząstka-Kłapyta, Kolędowanie na Huculszczyźnie, Kraków 2014, s. 357). 
przywoływana na końcu każdej zwrotki w formie krótkiego refrenu ${ }^{46}$. Między dronem a polifonicznymi teksturami głosowymi zachodzą często dysonansowe relacje. Realizacja tej techniki wokalnej u Aromanów bazuje na obsadzie zespołowej bez towarzyszenia instrumentalnego, w której panuje ściśle zhierarchizowany porządek wokalny. Wyróżnia się obsady męskie, żeńskie lub mieszane złożone z kobiet i mężczyzn. W większości przypadków każdą z prowadzonych linearnie melodii realizuje pojedynczo kilka śpiewaków, podczas gdy dron wykonuje cały zespół złożony z dowolnej liczby osób. W najniższej części brzmieniowej występują basowe burdony głosowe. Jak pisze Thede Kahl ${ }^{47}$; początkową linię melodyczną pieśni intonuje jeden śpiewak odgrywający rolę lidera. Po aromańsku nazywa się „lja canticle” (,bierze piosenkę”) lub „tradzi boatsea” (,,ciągnie głos”) lub ,atselu tsi u lja” (,ten, który bie-

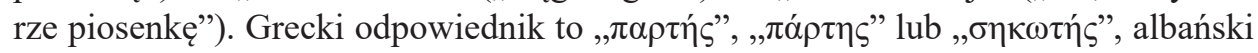
„marrës”. Drugi śpiewak wchodzi w środku lub na końcu pierwszego zdania w odległości sekundy, kwarty lub kwinty poniżej dźwięku centralnego skali. Po aromańsku nazywany „talji boatsea” (,,przerywa piosenkę") lub jako rzeczownik ,,atselu tsi u tal-

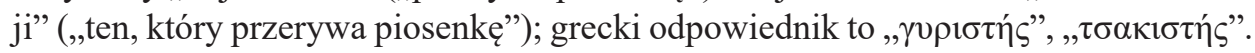
Trzeci solista - rzadko słyszany - używa kwarty poniżej dźwięku centralnego i śpiewa swoje partie na: ah, aide, lele, moi, lai, oo. U Aromanów nazywa się go ,arucă boatsea” (,ten, kto rzuca głos”), ,atselu” (,rzuca głos”); grecki odpowiednik to pí- $\chi \tau \eta \zeta$, albański - hedhës. Obecność trzeciego solisty wskazuje na tzw. „styl Lab” i stanowi wyjątek w aromanskiej muzyce wieloczęściowej. Reszta grupy śpiewa drona lub burdon na samogłosce „e” (rzadko „a”, „o”) na dźwięku centralnym skali. Wysokość dźwięku drona nie zawsze jest taka sama. Może być o sekundę wyższy lub schodzić o kwartę niżej od dźwięku centralnego. U Farszerotów dron nie jest polifoniczny, tak jak w wieloczęściowym śpiewie „Labs” ${ }^{48}$. Występuje w nim szeroka gama barw. Często samogłoska zmienia się podczas śpiewania tego samego dźwięku. Popularne jest też jakby pohukiwanie na głoskach „huhu...”49 z opadającą glisandową melodyką i długo wytrzymanymi punktami przystankowymi. Występowanie tej unikatowej, reliktowej starożytnej techniki wokalnej pokrywa się ze wszystkimi górskimi regionami Bałkanów zamieszkałymi przez Aromanów. Podobna technika wokalna występowała na Polesiu (pogranicze Rosji, Ukrainy, Białorusi), gdzie również dotarło osadnictwo wołoskie, notabene genetycznie starsze od zachodniokarpackiego ${ }^{50}$. Polifonia dronów bardzo rzadko występuje u Słowian Wschodnich, gdzie mogła dotrzeć jeszcze przed napływem fal migracyjnych z Azji Środkowej i Wschodniej (najbardziej

46 J. H. F. Brabner, The national encyclopaedia, t. 5, 1884, s. 99.

47 T. Kahl, Multipart singing among the Aromanians (Vlachs), [w:] European voices: multipart singing in the Balkans and the Mediterranean I, red. A. Ahmedaja, H. Gerlinde, Wien 2008, s. $274,275$.

48 Ibidem.

${ }^{49}$ Goga performed by Aristide Puiu \& Lealea Vanghele. Aromanian traditional folk song from the Farsherot community of Dobruja, https://www.youtube.com/watch?v=6EWVFonKmZk [dostęp: 16.07.2021].

50 G. Jawor, Kolonizacja wołoska na obszarach Wolynia w XV i XVI wieku, „Rocznik Lubelski” 2018, t. 44, s. $15-24$. 
monofonicznych regionów Eurazji ${ }^{51}$. Dlatego dominujące dla polifonii drona są górskie regiony Bałkanów. Dość jednorodne pod względem jego rozpowszechnienia jest terytorium Serbii. Z kolei jedynym regionem, w którym nie udokumentowano tej techniki jest południowo-zachodnia część Serbii i Kosowo. Wschodni serbski styl polifoniczny (a dokładniej styl południowo-wschodni) jest dość podobny do bułgarskiego i macedońskiego, z dronem w dolnej części i przewagą ostrych dysonansów. Bułgarskie tradycje polifonii głosowej występują tylko u Aromanów w południowozachodniej części kraju i stanowią głównie domenę mężczyzn (Piryn, Nedelino w Rodopach). Wykonywane są zespołowo w technice antyfonalnej, czyli w sposób dialogowany przez dwa zespoły chóralne. Drona zwykle wykonuje kilku śpiewaków, a linię melodyczną solista (lub soliści). Najbardziej znaną cechą bułgarskich śpiewów jest występowanie ostrych dysonansowych współbrzmień (sekundy, septymy), częste są stojące współbrzmienia kwartowe, kwintowe, sekundowe. W przebiegu linii melodycznej grup aromanskich dominują repetycje dźwiękowe, które często tworzą zwroty inicjalne, a także płynny ruch sekundowy, skoki kwartowo-tercjowe realizowane $\mathrm{W}$ swobodnej rytmice $\mathrm{z}$ rytmami punktowanymi i odwrotnie punktowanymi ${ }^{52}$. Starożytna polifonia dronów z wtórnymi dysonansami nie wykazuje jednak żadnych znaczących śladów wpływu monofonii melizmatycznej Azji Zachodniej, czy też klasycznej europejskiej polifonii ${ }^{53}$. W Rumunii, gdzie w muzyce ludowej dominuje monofonia wokalna, polifonia drona jawi się jako unikalna technika wokalna wyróżniająca tylko śpiewy żyjących w górach społeczności aromańskich (Banat, Dobrudża) ${ }^{54}$. Najbogatszą na Bałkanach i nie wykluczone, że na całym świecie jest polifonia południowej Albanii ${ }^{55}$, gdzie szczególne archaizmy zdołał przechować styl śpiewania mężczyzn (rubato, bogata melizmatyka). Śpiew kobiet jest bardziej stonowany, rytmicznie ściślej zorganizowany i mniej ozdobny, chociaż w miarę starzenia się kobiet lepsze śpiewaczki mogą przyjmować wirtuozowskie cechy męskiego repertuaru ${ }^{56}$. Albańska polifonia jest uznana za część narodowej tradycji albańskiej muzyki ludowej i znajduje się na liście niematerialnego dziedzictwa kulturowego UNESCO. Głęboko zakorzenioną w świadomości Aromanów tradycję śpiewania na głosy potwierdza spostrzeżenie Georga Marcu w odniesieniu do rumuńskich Farszerotów, którzy nie potrafią indywidualnie zaśpiewać własnej linii melodycznej bez towarzysze-

${ }^{51}$ W. Matvienko, On some peculiarities of Ukrainian traditional polyphony, „Ukrainian Musicology” 1967 , t. 2, s. $152-166$.

52 J. Jordania, Who ask the, s. 107.

53 Ibidem, s. 225.

54 George Marcu wyróżnia dwa polifoniczne style wokalne wśród Macedończyków w Rumunii: pierwszy jest związany z „Pinderi” (Macedończycy z gór Pindul) i „, Gramusteni "(głównie z Epiru północnej Grecji). Drugi styl prezentują Farsheroti; G. Marcu, Folclor muzical Aromân, Bucureşti 1977.

${ }^{55}$ Polifonia wokalna istnieje w czterech regionach południowej Albanii - Lalëria (Myzeqe), Toskëria, Çamëria i Labëria. Pokrewną formę śpiewu polifonicznego można znaleźć w północnej Albanii w rejonie Peszkopi; Polog, Tetowo, Kičevo i Gostivar w Macedonii i w południowej Czarnogórze; https:// en.wikipedia.org/wiki/Albanian_iso-polyphony.

56 International Reserch Center for Traditional polyphony; http://polyphony.ge/en/category/world/ centres-of-polyphony/page/3/ [dostęp: 16.07.2021]. 
nia wokalnego całej grupy śpiewaków. Śpiewak odpowie, że nie może wykonać sam swojej linii głosowej, dopóki nie będzie miał kogoś, kto „wyciszy głos” i wreszcie jeszcze jednego towarzyszącego głosu ${ }^{57}$. Charakterystyczną cechą śpiewów tej grupy jest występowanie dwóch linii melodycznych - głównej i kontrapunktu, realizowanych przez pojedynczych wykonawców na tle zespołowo realizowanego drona ${ }^{58}$ (przykł. 2). Pierwszy głos główny jest bardziej ruchliwy i ozdobny, przeważa w nim ruchu sekundowy z interwałami kwarty w postaci skoków descendentalnych na początku, w środku (przykł. 2) lub w zakończeniach muzycznych fraz (pieśń „Ia bagâțs stulia"). Melodia jakby meandruje z wyraźnie zaznaczającym się jej opadającym kierunkiem na końcach zdań muzyczno-tekstowych. W wykonaniu wyczuwa się dużą swobodę metro-rytmiczną. Drugi głos może być spokojniejszy, przepełniony repetycjami dźwiękowymi w formie rytmicznego burdonu ${ }^{59}$ albo może kontrapunktować głos pierwszy w jego zwariantowanej formie (kanon) (przykł. 2). Oba głosy jakby dialogują ze sobą, przy czym pierwszy zawsze wyprzedza głos towarzyszący solowym inicjowaniem melodii ${ }^{60}$. Analiza wybranych śpiewów Aromanów (łącznie około 150$)^{61}$ wykazała, że pieśni te wyróżniają się wybitnie archaicznym charakterem. Interesujące okazały się przykłady śpiewów w których uwidacznia się zdolność krzyżowania głosów (przykł. 8). Śpiew jest sylabiczny z melizmatami i recytatywno-deklamacyjną melodyką typu parlando-rubato z tendencją do opadania na końcach fraz muzycznych w oparciu o prymarny skok w górę kwarty czystej, bądź kwarty zwiększonej oraz z charakterystycznym zawieszeniem głosu na jej górnym dźwięku (kulminacyjny punkt $)^{62}$. Konstruktywny dla architektoniki melodii interwał kwarty przejawia się w niemal wszystkich analizowanych przykładach pieśniowych (przykł. 1-3, 5-8). Interwałami drugorzędnymi w przebiegi melodii są tercja i kwinta. Skoki interwałowe w górę zawsze zakończone są charakterystycznym spokojnym glissandowym zjazdem w obrębie kwarty. Melodie inicjowane są zwrotami opartymi na repetycjach dźwiękowych, bądź na skoku kwartowym. Wykonywane są w tempie powolnym i opierają się na wąskozakresowych skalach: trichordalnej, tetrachordalnej, pentachordalnej, heksachordalnej, pentatonice anhemitonicznej i skalach orientalnych: wołoskiej, z kwartą zwiększoną (lidyzacja) i bifurkacją IV stopnia. W przebiegu melodycznym przeważają dźwięki repetycyjne i ruch sekundowy i subkwartowe zakończenia kadencyjne (plagalizacja). Repertuar pieśniowy jest homogoniczny pod

57 G. Marcu, Folclor muzical, s. 41-42.

58 Ia bagâțs stulia/Îmbracă-ți ia/Put your shirt, https://www.youtube.com/watch?v=iVU-DJCuVoY [dostęp: 16.07.2021].

${ }^{59}$ Bună-ți oara, picurare/Bună ziua, păcurare, https://www.youtube.com/watch?v=8RGT-e5PcnQ [dostęp: 16.07.2021].

60 Dzeana iu-ți vineai/Dealul pe care veneai, https://www.youtube.com/watch?v=e6KC11FrqKg [dostęp: 16.07.2021].

61 Analizy pochodzą z nagrań dostępnych na stronach internetowych, płytach $\mathrm{CD}$ oraz pracy: I. Caranica, 130 Melodii Populare.

62 Pieśni z Aromanów z Macedonii: CD, Parea di Fârschirots di Nijopoli. Cântits Armânest, Bituli 2007. 
względem stylistycznym. Kolejne wykonania pieśni to warianty jakby podstawowej, najczęściej pięcio lub sześciodźwiękowej struktury melodycznej, którą rządzą wspomniane wyżej reguły. Coraz częściej spotkać można wykonania pozbawione wielogłosu-homofoniczne, które wynikają z braku wystarczającej ilości wyspecjalizowanych śpiewaków. Przyczyną tego jest m.in. rozbicie grupowe spowodowane wymieraniem starszej populacji i emigracją do miast generacji młodszej ${ }^{63}$. Problem ten jest zapewne szerszy i odnosi się do innych regionów zamieszkiwanych przez Vlachów. Trzyczęściowy śpiew może być również wykonywany bez drona. W tym przypadku trzecią część śpiewa niżej chór śpiewaków o sekundę wielką, tercję małą lub kwartę poniżej melodii pierwszego głosu (przykł. 7, 8). Głosy mogą łączyć się w niektórych frazach na unisonie, w innych tworzą relację seksty, kwarty czystej przechodzącej na kwintę itd. (przykł. 7) albo sekundy wielkich z możliwości krzyżowania się linii głosowych (przykł. 8). Godne uwagi są też znane np. Aromanom z Macedonii i analizowane przez mnie śpiewy wykazujące związki z melodyką karpacką: wąskozakresowe o sylabicznej melodyce, wykonywane dwugłosowo w interwale równoległych tercji. I w tym wypadku pieśń intonuje solo lider, po którym włącza się grupa pozostałych wokalistó $w^{64}$ kończących utwór frazami kadencyjnymi opierającymi się na zejściu głosów w unisonie.

\section{HETEROFONIA WARIACYJNA I WIELOGŁOS}

Drugą ważną techniką polifoniczną spotykaną na terytoriach etnicznie wołoskich jest heterofonia wariacyjna. Opiera się na linearnym sposobie myślenia w kształtowaniu poszczególnych linii melodycznych, które są wypadkową współbrzmienia różnych jednocześnie wykonywanych wariantów melodycznych w efekcie którego tworzą różne zależności interwałowe między głosami ${ }^{65}$. Technika ta zalicza się po polifonii drona do najstarszych przejawów wielogłosowości ludowej. Wiąże się ona z najbardziej archaicznymi w Karpatach formami śpiewu zaznaczającymi się szczególnie wyraźnie w repertuarze obrzędowym, a zwłaszcza pasterskim. Zwłaszcza śpiewy pasterskie są wyzwolone od wszelkiego schematyzmu, konstruktywizmu formalnego i nasycone są archaicznymi manierami wykonawczymi, o których napiszę w dalszej części rozważań. Heterofonia wariacyjna pojawia się w źródłach pisanych od $\mathrm{XV}$ wieku ${ }^{66}$. Kolebką śpiewu heterofonicznego jest terytorium etniczne ludności rosyjskiej, ukraińskiej i białoruskiej ${ }^{67}$. Nie może zatem dziwić fakt występowania jej u Rusinów karpackich i częściowo u górali pienińskich, którzy sąsiadowali i czę-

${ }^{63}$ K. Thede, Multipart singing, s. 274.

${ }^{64} \mathrm{CD}$, Parea di Fârschirots di Nijopoli, przykłady 11 i 12.

65 J. Stęszewski, Muzyka Ludowa, s. 245.

${ }^{66}$ P. Dahlig, Tradycyjny śpiew wielogłosowy w Polsce $w$ perspektywie etnomuzykologii, „Łódzkie Studia Etnograficzne" 2018, t. 57, s. 11.

${ }^{67} \mathrm{~J}$. Jordania, Who ask the, s. 227. 
ściowo mieszali się z etnicznym żywiołem karpatoruskim. Doskonałe przykłady tej techniki udało się zarejestrować na początku XXI wieku w Osturni na słowackim Zamagurzu spiskim ${ }^{68}$. Oddziaływanie heterofonicznej techniki śpiewu na ludność zamieszkującą Karpaty mogło iść tylko i wyłącznie ze wschodu i południowego wschodu, z terenów Zakarpacia, gdzie także rozpowszechniony jest ten styl śpiewania. Szlak tych wpływów pokrywa się z kierunkiem migracji etnosu wołoskiego w Karpatach Wschodnich.

\section{KARPATORUSIŃSKA POLIFONIA - ECHO TECHNIKI TYPU DRONE}

Według Oskara i Alicji Elscheków południowozachodnie i zachodnie Bałkany posiadają wokalny typ dialektyki muzycznej, która nie pozostaje w żadnym bezpośrednim związku z tradycją wokalną ukraińskich, słowackich i polskich Karpat ${ }^{69}$. Bezpośrednich na pewno nie, ale pośrednich być może. Czy wniosek ten można zatem traktować jako ostateczne źródło rozstrzygające problematykę wołoską w muzyce Karpat? Okazuje się, że pewien reliktowy ślad rozpowszechnionej najprawdopodobniej kiedyś szerzej techniki drona na gruncie wschodniosłowiańskim przetrwał w polifonii wokalnej karpackich Rusinów. Pewnymi przesłankami mogą tu być m.in.; spotykane w ich śpiewie typowe dla polifonii drona dysonansowe współbrzmienia, burdony głosowe w formie rytmicznych powtórzeń lub pedałów (na gruncie muzyki instrumentalnej Hucułów) oraz melizmatyczny i deklamacyjny styl śpiewu. Szczególnie interesującym przykładem jest wykonywana $\mathrm{w}$ obsadzie zespołowej bez towarzyszenia instrumentalnego żeńska špyvanka polanowa - Majdany ${ }^{70}$ z Litmanovej (Słowacja) (przykł. 14), której żywotność określa jej rozpowszechnienie w różnych postaciach wariantowych w okolicznych wioskach rusińskich (Kamionka, Velki Lipnik) znajdujących się na terenie historycznego Spisza. Przykład ten w swoim brzmieniu przypomina wyraźnie echo polifonii drona ${ }^{71}$, a zwłaszcza bułgarskich śpiewów na głosy $\mathrm{z}$ dysonansami (sekundy, kwarty) ${ }^{72}$. Melodia tej pieśni ma nawet w pierwszym słuchowym odczuciu charakter orientalny i opiera się na spotykanym w repertuarze Rusinów i często występującym w polifonii Aromanów tetrachordzie z III stopniem obniżonym, z subsemitonium modii oraz subkwartą w zakończeniach fraz muzycznych, która jest interwałem reprezentatywnym w muzyce zarówno Karpatorusinów (w zakończeniach

68 Por. J. Cząstka, Charakterystyka etnomuzyczna wsi Osturnia, dynamika przemian repertuaru muzycznego, praca magisterska pod kier. Jana Stęszewskiego, Instytut Muzykologii UJ, Kraków 2007.

69 O. Elschek, Stratigraphische Probleme der Volksmusik in den Karpaten und auf den Balkan, Bratislava 1981

${ }^{70}$ Majdany - lokalna nazwa sezonowych letnich wypasów trzód owiec, krów na górskich łąkach, od słowa majdan (szopa).

${ }^{71}$ Majdany, Litmanova, https://www.youtube.com/watch?v=fyeAn4L7ttc [dostęp: 16.07.2021].

72 Dysonansowe współbrzmienia między głosami występują głównie w repertuarze pieśniowym Karpatorusinów w regionie górnego Spisza i Sarisza: K. Bičanová, Piesňovy repertoár Rusinov, s. 299. 
fraz) jak i Aromanów (Farszeroci) ${ }^{73}$. Podobieństwo z aromańską stylistyką melodyczną i wielogłosową jest jeszcze bardziej zadziwiające, gdy zestawi się omawiany tu przykład z przykładem zarejestrowanym w Grecji w górach Pindos (przykł. 1). Zapis wariantu aromańskiego jest bardzo uproszczony (metrycznie, brakuje tekstu). W obu przypadkach tempo wykonania pieśni jest powolne, melodyka opiera się na skali tetrachordalnej z III stopniem obniżonym, w wariancie bałkańskim rozszerzonej do pentachordu (przez jeden dźwięk „c”). Także oba przykłady realizowane są w swobodnym metrum, w dwugłosie, zwłaszcza w przykładzie z Litmanowej, który otwiera solowy zaśpiew lidera oparty na 6 sylabowym zwrocie, po którym w interwale tercji poniżej głosu lidera wchodzi reszta głosów - w wariancie bałkańskim od początku w tym interwale. Głosy poruszają się w stosunku do głównej, solowo realizowanej melodii (Litmanowa) w charakterze powtarzanych na jednej wysokości dźwięków burdonowych dostosowanych rytmicznie do górnego głosu. W jednym i drugim przypadku między głosami powstają współbrzmienia dysonansowo-konsonansowe: sekund, tercji, kwart i kwint. W zakończeniach kadencyjnych głosy łączą się na unisonie. Melodyka obu pieśni porusza się krokami sekundowymi przeplatanymi zwrotami repetycyjnymi. Przykład z Litmanowej można uznać za możliwy relikt starych aromańskich praktyk śpiewania na głosy zawleczonych w te strony (południowy skłon pasma Małych Pienin) za pośrednictwem wołoskim. Warto dodać, że Rusini z Litmanowej przechowali także inne cenne maniery wykonawcze - unikatową i rzadko już spotykaną w repertuarze tzw. špyvanek paribskich ${ }^{74}$ (męskich pieśni) manierę związaną z glissandowym ześlizgnięciem się w obrębie subkwarty poniżej dźwięku centralnego w zwrocie kadencyjnym. Maniera ta brzmi archaicznie, tym bardziej, że towarzyszy jej melodyka oparta na archaicznej wąskozakresowej skali trichordalnej ${ }^{75}$. Glissandowanie było kiedyś szerzej rozpowszechnione u innych grup karpatorusińskich oraz w innych regionach Karpat (np. na Podhalu i w Pieninach) ${ }^{76}$. Wiązało się też ze zwrotami melodycznymi kończącymi i zawołania pasterskie, które przez swój descendentalny kierunek melodyki, ametryczność, swobodę wykonawczą i improwizacyjny charakter mogły oddziaływać na stylistykę wykonawczą oraz budowę formalną karpackich śpiewów pasterskich ${ }^{77}$. Nie można też wykluczyć, że są reliktową, skamieniałą formą jakiś pierwotnych śpiewów ${ }^{78}$. Największą żywotność glissandowania przedstawiają do dziś śpiewy Vlachów np. z Macedonii ${ }^{79}$.

\footnotetext{
73 J. Jordania, Who ask the, s. 106.

${ }^{74}$ Projekt i film Muzyka bez Granic; https://www.youtube.com/watch?v=8V9ADJ2g9VY\&t=847s [dostęp; 16.07.2021].

${ }^{75}$ CD-DVD, Muzyka bez granic. Pogranicze Pienin, red. J. Cząstka-Kłapyta, Kraków 2017, przyk$\operatorname{lad} 5$.

76 W. Kotoński, Uwagi o muzyce ludowej Podhala, cz. III (O twórczym sposobie wykonania), „Muzyka” 1957, nr. 11/12, s. 32.

77 Z. Przerembski, O niektórych archaicznych cechach górali podhalańskich, „Muzyka” 1989, nr 4, s. 36,39 .

${ }^{78}$ Ibidem, s. 39, 40.

${ }^{79}$ Vlach Song from Macedonia-Atanase Iorghitsa, https://www.youtube.com/watch?v=ey_XJe1_iIc [dostęp: 16.07.2021].
} 
Kolejnym stylistycznym archaizmem wykonawczym o prawdopodobnie wołoskim rodowodzie jest stosowanie szerokich fraz oddechowych i krótkich oddechów przerywających frazy muzyczne przed ostatnim słowem kończącej się frazy, co powoduje wyraźne przesunięcia akcentów z pierwszej na ostatnią sylabę poprzedzającą kolejną frazę wypowiedzi słowno-muzycznych ${ }^{80}$. Ta archaiczna maniera wykonawcza, swoiście rozczłonkowująca tok płynnej narracji słowno-muzycznej była do niedawna szeroko rozpowszechniona w repertuarze pieśniowym Rusinów z Osturni (przykł. 12), a swoją żywotność zdołała zachować na Huculszczyźnie np. w śpiewie kolęd (tzw. „żekanek") ${ }^{81}$, których największe centrum znajduje się w regionie Kosmacza ${ }^{82}$, a także w pasterskich śpiewach w Rodopach (Bułgaria) ${ }^{83}$. Inną cechą wspólną dla dialektyki wokalnej Aromanów i Karpatorusinów (Osturnia, Huculszczyzna, Bojkowszczyzna ${ }^{84}$ ) są przedzielone pochodami sekundowymi sekwencje oparte na motywach repetycyjnych, które mniej lub bardziej tworzą deklamacyjny typ wypowiedzi słowno-muzycznej przykł. $(12,15)^{85}$ i mogą stanowić reliktowe ślady polifonii drona.

\section{MELODYKA, SKALE I METRO-RYTMIKA}

W chronologicznie najstarszych warstwach karpackiego repertuaru pieśniowego (obrzędowego) występują często skale wąskozakresowe o zabarwieniu orientalnym: wołoska, lidyjska. Pieśni górali pienińskich (piosnecki, śpiewki), podhalańskich i rusińskich (̌̌pyvanky), żywieckich i śląskich opierają się na skalach: trichordalnych, tetrachordalnych, pentachordalnych, heksachordalnych ${ }^{86}$. Największe zagęszczenie skali wołoskiej występuje w muzyce Hucułów. Na skalę wołoską z obniżonym III i podwyższonym IV stopniem stosuje wiele badaczy folkloru określenie: wołoska lub cygańska. Nie można wykluczyć, że występująca w tej skali sekunda zwiększona mogła przedostać się do muzyki góralskiej za pośrednictwem wędrówek wołoskich, na co może wskazywać także fakt jej szerokiego rozprzestrzenienia w repertuarze muzycznym Bałkanów, Bułgarii, Rumunii i Huculszczyzny ${ }^{87}$. Hipotezę o wołoskim pochodzeniu tej skali mogą potwierdzać także badania struktury melodycznej pieś-

80 CD-DVD, Muzyka bez granic, przykład 5.

81 J. Cząstka-Kłapyta, Kolędowanie na Huculszczyźnie, s. 276-281.

82 „Żekanki” - nazwa tych kolęd wywodzi się od rozbitej cząstki refrenowej „Daj Bo/że”, która zalicza się do najstarszych huculskich refrenów kolędniczych; ibidem.

83 Rufinka bolna legnala (Руфинка болна легнала), https://www.youtube.com/watch?v=9QR2MUt TkqA [dostęp: 16.07.2021]. Tekst i fraza muzyczna ulega rozbiciu przez krótki oddech frazowy np.: Rufinka bolna le/gnala. Na visoka na pla/nina. Nikoj do neja ne/maše.

${ }^{84}$ Informacja na podstawie analizy nagrań z regionu Bojkowszczyzny pochodzących z archiwum: www.folk.org.ua [dostęp: 16.07.2021].

85 I. Caranica, 130 Melodii Populare.

86 J. Cząstka-Kłapyta, Pieniny - region pogranicza, [w:] CD-DVD, Muzyka bez granic, s. 1-9.

87 Idem, Wpływy wołoskie w folklorze muzycznym Karpat ze szczególnym uwzględnieniem Rusińskiej wsi Osturnia - przyczynek do rozważań [w:] Wołoskie dziedzictwo Karpat, Czeski Cieszyn 2007, s. 59. 
ni górali Beskidu Śląskiego ${ }^{88}$. Orientalny wydźwięk o nie wiadomym do końca pochodzeniu ma też skala podhalańska z podwyższonym czwartym i obniżonym siódmym stopniem, której domeną występowania jest region Podhala i Orawy. Lidyzmy (podwyższony 4 stopień skali) są częste w muzyce karpackiej po zachodnie jej krańce (Beskid Żywiecki, Śląski, Morawski) $^{89}$. Pod tym względem śpiewy podhalańskie są bliższe północnozachodniej Słowacji, ale cechują je także pewne związki z regionem Horehronia (środkowa Słowacja) ${ }^{90}$, co ewentualnie mogłoby przemawiać za południowo-zachodnim kierunkem oddziaływania muzycznych wpływów na Podhale. Znają też lidyzmy grupy śpiewaków aromańskich (przykł.2), oprócz często wykorzystywanej pentatoniki anhemitonicznej ${ }^{91}$. Inną cechą tonalną rozpowszechnioną na terytorium karpackim i u Aromanów jest stosowanie zmiennego intonowania III (przykł. 3), IV lub VII stopnia skali, które powoduje wahania trybu (np. w Macedonii) ${ }^{92}$. Zwrócił na nie uwagę ukraiński etnomuzykolog Filaret Kołessa, tłumacząc pochodzenie tego muzycznego zjawiska wpływami orientalnymi, tureckimi i tatarskimi, bądź możliwością nałożenia się różnych skal ${ }^{13}$.

Kolejnym elementem łączącym tradycję wokalną Karpat i Bałkanów może być swoboda rytmiczna, w Karpatach szczególnie odnosząca się do repertuaru wykonywanego na wolnej przestrzeni jak np. nuty wierchowe (Podhale), nuty juhaskie (Osturnia), polanowe (Pieniny - Rusini i górale pienińscy), spiwanky polonynskie (Huculszczyzna), spiwanky pasterskie (Łemkoszczyzna) itp ${ }^{94}$. Jednak tu trzeba zaznaczyć, że jest to cecha nie wyróżniająca regionu Karpat, ale typowa dla niemal całej tradycyjnej europejskiej ludowej kultury polifonicznej. Pewne analogie można szukać w metro-rytmice karpackich form pieśniowych, a zwłaszcza do jej ukształtowań w repertuarze pasterskim, gdzie jest dostosowana do rytmu toku sylabicznego i cechuje ją nieraz daleko posunięta swoboda wykonawcza wychodząca poza rygory metryczne (ametryczność) ${ }^{95}$ (przykł. 13, 15). Karpackie metra są przeważnie parzyste, u Karpatorusinów spotkać można także trójmiar. W budowie wersów słownych przeważają układy dwunastozgłoskowe ze średniówką (6+6) z interiekcjami: ej, hej. Z kolei w repertuarze grup rusińskich typowe są układy ośmiozgłoskowe (4+4), spotykane także u górali pienińskich. W tym kontekście metryka i rytmika śpiewów aro-

${ }^{88}$ A. Domaradzka-Barbier, Praktyka muzyczna górali śląskich-analiza śpiewów beskidzkich i próba wyodrębnienia modelu struktury melodycznej, „Muzyka” 2001, nr 3, s. 51-64.

89 A. Kopoczek, Folklor muzyczny Beskidu Ślaskiego, Katowice 1993, s. 17.

90 Z. Przerembski, Muzyka ludowa po obu stronach Tatr, s. 49 za: S. Burlasová, Viachlasný spev na Horehroní, [w:] Interetnické vzt'ahy vo folklóre karpatskej oblasti, red. V. Gašparíková, Bratislava 1980, s. 220 .

91 I. Caranica, 130 Melodii Populare, s. 7.

92 Dzeana iu-ți vineai/Dealul pe care veneai, https://www.youtube.com/watch?v=e6KC11FrqKg [dostęp: 16.07.2021].

${ }_{93}$ A. Kopoczek, Folklor muzyczny Beskidu Ślaskiego, Katowice 1993.

94 Tradycje polifoniczne o takich cechach występują u Aromanów południowo-albańskich, macedońskich, bułgarskich (z Pirynu), greckich (Epir) i serbskich; J. Jordania, Who asked the.

95 J. Cząstka-Kłapyta, Folklor muzyczny, [w:] Kultura Ludowa Górali Pienińskich, red. K. Ceklarz, U. Janicka-Krzywda, Kraków 2014, s. 515; J. Jordania, Who asked the, s. 221. 
mańskich jest bardzo zbliżona do karpackiej, chociaż jest znacznie bardziej złożona w swojej linearnej i wertykalnej formie. W polifonicznych liniach głosowych zdaje się jakby płynąć równomiernie z regularną pulsacją metryczną wyraźnymi zwolnieniami na końcach fraz muzyczno-tekstowych ${ }^{96}$. W układach, gdzie wyczuwalne jest metrum występują u Aromanów metra: 2/4, 3/4, 4/4, 6/877, rzadko spotkać można pięciomiar $5 / 8$ oraz metrum $9 / 8^{98}$. Najbardziej złożone, kombinowane układy metryczne występują w Bułgarii. Ważny jest tu wniosek, że zarówno bałkańska i karpacka rytmika jest descendentalna ${ }^{99} \mathrm{~W}$ ramach poszczególnych fraz muzyczno-tekstowych. Zresztą w regionach karpackich descendentalność rytmiczna należy do podstawowych cech strukturalnych ${ }^{100}$. Także $\mathrm{w}$ obu przypadkach częste jest stosowanie rytmów punktowanych i odwrotnie punktowanych. W tym wypadku bałkańska rytmika zbliża się bardziej do starowickich form spiwankowych Hucułów. W budowie wersów słownych u Aromanów przeważają, podobnie jak w Karpatach układy sześcio i ośmio sylabiczne (jak u Karpatorusinów), przedłużane krótkimi cząstkami słownymi typu: moi, mori, dada, oi, lele ${ }^{101}$. Pewien wspólny element może stanowić pięciomiar, dziś już nie spotykany w repertuarze regionalnych grup śpiewających. Został odkryty na obszarze polskich Karpat w rejonie Pienin i Beskidu Sądeckiego przez Jadwigę Sobieską, przy okazji analizowania pieśni tamtych regionów. Trzy przykłady pięciomiaru udało mi się zarejestrować w Osturni ${ }^{102}$. Jadwiga Sobieska uważa takie metrum za relikt powołoski, a dokładniej ślad starobułgarskich rytmów tanecznych. Spostrzeżenie to nigdy jednak nie zostało poddane szerszej refleksji ${ }^{103}$.

\section{STYL MELIZMATYCZNY}

Niezwykle ważnym elementem bałkańskich śpiewów jest bogata melizmatyka, szczątkowo zachowana w Karpatach w postaci krótkich zwrotów melodycznych, najczęściej wypełniających większe odległości interwałowe o descendentalnej melodyce opartej na jednej lub kilku sylabach tekstu słownego (przykł. 2, 3, 6, 12, 15). Z melizmatami wiąże się specyficzny sposób śpiewania zwany przez etnomuzykologów „stylem melizmatycznym”. Łączy się on z pewną kategorią melodyki - meandrującej z descendentalnymi zakończeniami, w której przeważa ruch sekundowy, międzyfrazowe skoki kwartowe i rodzaj fonacji głosowej przypominającej ześlizgiwanie się po dźwiękach w dół - ,glissandowanie”, czyli ścisłe łączenie dźwięków w literaturze

\footnotetext{
96 K. Thede, Multipart singing, s. 273.

97 I. Caranica, 130 Melodii Populare, s. 7.

98 K. Thede, Multipart singing, s. 274.

99 Descendetalna rytmika polega na przechodzeniu od krótkich do długich wartości rytmicznych.

100 Z. Przerembski, Muzyka ludowa po obu stronach Tatr, s. 50, za: A. Elscheková, Časová asymetria v slovenských l'udových piesñach”, [w:] Interetnické vzt’ahy vo folklóre, s. 230-231.

101 K. Thede, Multipart singing, s. 274.

102 J. Cząstka, Charakterystyka etnomuzyczna wsi Osturnia, przykłady 10, 23, 24 (aneks).

103 Idem, Wplywy wołoskie w folklorze muzycznym Karpat, s. 59.
} 
przedmiotu określane jako „,cercarela nota”. Śpiew ujęty jest wtedy w ramy szeroko zakrojonych łuków oddechowych wypełniających poszczególne frazy muzyczno-tekstowe $^{104}$. W Karpatach styl melizmatyczny przenika i zasadniczo łączy się najczęściej z kategorią repertuaru pasterskiego. Występuje najwyraźniej u Karpatorusinów (Hucułów, Bojków, Łemków, Rusinów spiskich i pienińskich), w Pieninach (Ruś Szlachtowska) ${ }^{105}$, na Spiszu polskim i słowackim (Zamagurze spiskie) ${ }^{106}$, a także u Górali Śląskich i Żywieckich oraz w najmniejszym stopniu na Podhalu i Orawie.

\section{DYMORFICZNA AUTOKLASYFIKACJA REPERTUARU PIEŚNIOWEGO}

Zarówno Karpatorusini jak i Aromanie znają wewnątrzkulturowy podział repertuaru pasterskiego ze względu na płeć, czuli na nuty ${ }^{107}$ męskie i żeńskie. Przykładowo w Osturni spiwanky osturniańskie dzielą się m.in. na pasterskie tzw. juhaskie, które przeznaczone są do wykonania przez mężczyzn i charakteryzują się występowaniem nut o specyficznym pasterskim charakterze (melizmatyka, descendentalna melodyka itp. $)^{108}$. Z kolei w Litmanowej i w innych sąsiednich wioskach rusińskich, w tym na byłej Rusi Szlachtowskiej dzieli się ten repertuar na špywanky polanowe/majdanowe lub żeńskie i paribskie/chłopskie (Rusini Szlachtowscy) ${ }^{109}$. Ta kategoria śpiewów jest przez te grupy Rusinów z Małych Pienin traktowana bardziej uniwersalnie (jak u górali Pienińskich) i ich wykonanie odbywać się mogło nie tylko przy pasieniu, ale także przy koszeniu i grabieniu. Można zatem założyć, że spotykany w autoklasyfikacji repertuaru pieśniowego podział repertuaru pieśniowego ze względu na płeć, którego kryterium jest odmienny charakter melodii ( $n u t)$ może być śladem wpływów bałkańskich na tradycję muzyczną Karpat. W tym miejscu można dodać, że wg. Ioana Caranica, u Aromanów jednak nie występuje tak luźny związek tekstu i melodii, jak ma to miejsce w góralskich nutach. Badacz twierdzi, że melodie są bardziej związane z tekstem, a warianty danych melodii rzadko występują w danej wsi i spotykane są raczej tylko w innych osadach ${ }^{110}$. Wobec braku uzasadnionych dowodów, kwestie tą na-

104 Idem, Kolędowanie na Huculszczyźnie, s. 269, 270.

105 W skład byłej Rusi Szlachtowskiej wchodziły wsie: Biała Woda, Czarna Woda, Jaworki, Szlachtowa). Wsiami graniczącymi dziś od strony słowackiej z Rusią Szlachtowską są osady rusińskie: Litmanowa, Kamionka, Velki Lipnik.

106 J. Cząstka-Kłapyta, Wptywy wołoskie w folklorze muzycznym, s. 56.

107 Nuta w muzyce górali karpackich oznacza pojęcie szersze niż melodia. W nutach podhalańskich pierwszorzędną rolę odgrywa harmonia, natomiast u Karpatorusinów i górali pienińskich większe znaczenie ma melodyka. Nuta dopuszcza dowolną liczbę różnych pod względem rytmicznym i motywicznym melodii oraz luźny związek tekstu z melodią.

108 J. Cząstka-Kłapyta, Autoklasyfikacja repertuaru muzycznego na przykładzie rusińskiej wsi Osturnia (Zamagurze Spiskie), [w:] Huculi, Bojkowie, Łemkowie - tradycja i współczesność, red. J. Cząstka-Kłapyta, Kraków 2008, s. 131.

${ }^{109}$ Idem, Pieniny - region pogranicza; wstęp do wydania płyty CD-DVD, Muzyka bez granic; także: https://www.youtube.com/watch?v=8V9ADJ2g9VY [dostęp: 16.07.2021].

110 I. Caranica, 130 Melodii Populare, s. 8. 
leżałoby dokładniej przeanalizować w terenie analizując różne warianty obiegowych melodii w wioskach zamieszkiwanych przez Aromanów.

\section{TETRACHORDALNA BUDOWA FRAZ MUZYCZNYCH, PRYMARNY INTERWAŁ KWARTY}

Dla zrozumienia specyfiki melodyki wołoskiej ważne znaczenie ma prześledzenie jej architektoniki. Analiza meliczna różnych wybranych języków muzycznych na omawianym obszarze bałkańsko-karpackim wykazała, że kluczowa dla morfologii melodyki jest tetrachordalna budowa fraz muzycznych, meandrująca i descendentalna melodyka zwłaszcza w zakończeniach fraz kadencyjnych. Te cechy najwyraźniej zaznaczają się na Bałkanach oraz u Karpatorusinów ${ }^{111}$, górali pienińskich, podhalańskich i orawskich ${ }^{112}$, gdzie u dwóch ostatnich nieco rzadziej występują tetrachordalne struktury frazowe. Descendentalna melodyka jest cechą ogólnie wyróżniającą melodykę karpacką, chociaż u Hucułów i innych Karpatorusinów i Aromanów występuje częściej w zakończeniach fraz łącząc się z meandrującą melodyką (przykł. 6, 7, 8, 13, 15) i deklamacyjnym tokiem wypowiedzi słowno-muzycznej ${ }^{113}$. Największą tendencję do descendentalnej melodyki posiadają śpiewy Podhala i Pienin (wraz z Rusinami Szlachtowskimi) (przykł. 10,11). Opadający kierunek linii melodycznych należy do najbardziej archetypowych przejawów muzyki i jest jedną z cech melodii w tzw. „starym stylu”"14. Interesujące pod tym względem są też przykłady z Bojkowszyzny (Nedilna, Stary Sambor), w których frazy opierają się konsekwentnie na opadających strukturach melodycznych w obrębie zbudowanych na tetrachordzie fraz muzycznych ${ }^{115}$. Descendentalność melodyki łączy się zatem wyraźnie z tetrachordalną budową fraz. Na taką budowę strukturalną fraz muzycznych w Karpatach zwrócili po raz pierwszy uwagę w polskiej etnomuzykologii Jadwiga i Marian Sobiescy analizując

111 Cechę ta dostrzegł także Janusz Mroczek analizując melodykę łemkowskich pieśni pasterskich. Wskazuje też na inne cechy dystynktywne: wydłużanie wartości rytmicznych w kadencjach i w punktach kulminacyjnych, wolne tempo, rubato, chwiejność intonacji, reminiscencje melizmatyki, glissandowe poślizgi dźwięków incypitowych i opadających w kadencjach, tetrachordy i pentachordy budujące frazy itp.; J. Mroczek, Ze studiów nad melodiami temkowskich pieśni pasterskich, „Materiały Budownictwa Ludowego" 1973, nr 17-18, s. 51.

112 B. Lewandowska, Folklor Muzyczny [w:] Kultura Ludowa Górali Orawskich, red. U. Janicka-Krzywda, Kraków 2011, s. 269-302; Pieśni z Orawy, red. B. Lewandowska, J. Kąś, Kraków 2007.

113 Obecnie w wykonaniu spiwanek huculskich dominuje falisty rysunek linii melodycznej z tendencja do opadania w zakończeniach fraz muzycznych. Opadającą melodykę miały wyparte przypuszczalnie przed II wojną światową stare śpiewy pasterskie wypełnione bogata melizmatyką.

114 Z. Przerembski, O niektórych archaicznych cechach, s. 40 [za:] B. Bartók, Das ungarische Volkslied, s. 13-44.

115 Informacja na podstawie analizy odsłuchowej nagrań archiwalnych $(1932,1997,1998)$; www. folk.org.ua [dostęp: 16.07.2021]. 
melodykę pieśni górali pienińskich ${ }^{116}$ (przykł. 11). Sobiescy musieli jednak nie zdawać sobie sprawy, że ta specyficzna cecha muzyczna występuje nie tylko na Podhalu, ale u wszystkich górali ruskich. Zatem im dalej w kierunku Karpat Wschodnich, tym bardziej kwartowe frazy nabierają prymarnego znaczenia ${ }^{117}$ (przykł. 10, 12, 13). Cecha ta uwidacznia się zwłaszcza u górali pienińskich, których tradycja muzyczna w swoich najbardziej archaicznych przejawach jest najprawdopodobniej głęboko zakorzeniona $\mathrm{w}$ tradycji karpatorusińskiej. Pomiędzy repertuarem wokalnym górali pienińskich i Rusinów Szlachtowskich (wysiedlonych w 1947 roku) i tych mieszkających po drugiej stronie granicy zachodzi bowiem wiele muzycznych związków, co poparte zostało badaniami terenowymi ${ }^{118}$. U górali pienińskich, rusińskich, podhalańskich i orawskich strukturom frazowym zamkniętym w obrębie kwarty towarzyszą długo wytrzymywane punkty spoczynkowe na końcach fraz muzyczno-tekstowych i opadający (descendentalny) kierunek linii melodycznej (szczególnie u górali pienińskich), który umożliwia dokładanie od góry i od dołu innych głosów. W Beskidzie Śląskim tetrachordalnej budowie fraz towarzyszą zwroty oparte na skali wołoskiej (z małą tercją i sekundą zwiększoną). Z kolei tetrachordy z sekundą zwiększoną między II a III stopniem są charakterystyczne dla pieśni ludowych Słowacji, Czech i Moraw, Rumunii, Węgier, Bułgarii, Serbii i Macedonii, a także dla muzyki hinduskiej, arabskiej, tureckiej i cygańskiej ${ }^{119}$. Na Słowacji taką budowę mają stare tzw. „wałaskie” pieśni z Detvy (Słowacja), które według Beli Bartóka (1951) należą do jednych z najstarszych warstw słowackiej muzyki ludowej ${ }^{120}$. Badacz ten wywodzi tetrachordalną budowę fraz muzycznych od skali instrumentu pasterskiego bez otworów bocznych - fujary, instrumentu znanego w tradycji Karpat i Bałkanów, a jej pojawienie się w ludowej muzyce słowackiej wiąże ze starożytnymi wpływami w Karpatach (greckimi lub trackimi), przyniesionymi za pośrednictwem migracji wołoskich. Podobne cechy stylistyczne występujące w melodyce górali pienińskich, detviańskich i rusińskich występują także u Aromanów; tetrachordalna budowa fraz muzycznych połączona z meandrującym typem melodyki (przykł. 5, 6, 7). Podobnie częste w śpiewach aromańskich są długo utrzymujące się punkty spoczynkowe w kulminacyjnych punktach melodii i subkwartowe odniesienia z sekundą zwiększoną pomiędzy II a III stopniem, które stanowią zakończenia pieśniowych fraz muzycznych ${ }^{121}$. Przypominają one archaiczne formy karpackich zawołań pasterskich. Zawołania pasterskie pełniły funkcję komunikacyjną na otwartych przestrzeniach górskich. W zależności od regio-

116 J., M. Sobiescy, Diafonia w Pieninach, „Muzyka” 1952, nr 9, s. 15-29; przedruk: J., M. Sobiescy, Polska muzyka ludowa i jej problemy. Wybór prac, red. L. Bielawski, Kraków 1973, s. 344-360.

117 Za przykład można tu przywołać wyniki analizy weselnego repertuaru Łemków pisze o tym Bogumiła Tarasiewicz, Wesele Łemkowskie. Obrzęd i muzyka. Tradycja i współczesność, Legnica 2009, s. 222. Kwartowe odniesienia w melodyce szczególnie wyraźnie zaznaczają się także w repertuarze Hucułów np. w kolędach: J. Cząstka-Kłapyta, Kolędowanie na Huculszczyźnie, s. 267, 268.

118 CD-DVD, Muzyka bez granic.

119 A. Kopoczek, Folklor muzyczny, s. 19.

120 J. Kresanek, Slovenská ludová pieseň so stanoviska hudobného, Bratislava 1951, s. 42.

121 Goga, https://www.youtube.com/watch?v=6EWVFonKmZk [dostęp: 16.07.2021]. 
nu stosowano na nie różne określenia: wyskanie (Podhale), ujkanie (Osturnia), hiłkanie (Łemkowszczyzna), ehokanie (Huculszczyzna), helokanie (Beskid Śląski) ${ }^{122}$ itp. Podobne zasady odnoszą się do charakteru melodii wygrywanych na wspomnianych wcześniej instrumentach muzycznych ${ }^{123}$. Cechy te u Aromanów w audytywnym odbiorze wydają się być niezauważalne ze względu na zacierający je bogaty melizmatyczny styl śpiewu i złożone warstwy brzmieniowe polifonicznej tekstury. Przykładem mogą być śpiewy Faszerotów z Rumunii (Dobrudża) ${ }^{124}$. Charakterystyczne dla melodyki Aromanów i a zwłaszcza Karpatorusinów, a także górali pienińskich oraz w mniejszym stopniu pozostałych grup górali karpackich jest prymarne znaczenie interwału kwarty, która może być realizowana zarówno jako interwał inicjalny (przykł. 2), międzyfrazowy (przykł. 3, 5, 7, 8) i zwrot kadencyjny (przykł. 12, 13) ${ }^{125}$. Wszystkie trzy możliwości występują z największą częstotliwością u Aromanów i Karpatorusinów. Taka struktura interwałowa występuje w śpiewie Faszerotów z Dobrudży (Rumunia), gdzie pojawia się jako skok kwarty w górę w zwrotach inicjalnych i w zakończeniach fraz muzyczno-tekstowych ${ }^{126}$. W przebiegu melodycznym przeważa ruch sekundowy z tercjami oprócz kwart i z fermatami zawieszonymi na ich górnym stopniu (punkty kulminacyjne). Skoki kwartowe w dół w zakończeniach kadencyjnych wypełniane są glissandowymi przejściami. Identyczne cechy odnajdujemy w Karpatach Wschodnich (u Bojków, Hucułów), gdzie występują tendencję do kwartowych skoków w górę w zwrotach inicjalnych i w dół, w zwrotach kadencyjnych. $\mathrm{W}$ innych regionach karpackich kwarta występuje z reguły jako interwał międzyfrazowy, a jako inicjalny tylko w repertuarze pieśniowym górali pienińskich, górali podhalańskich, orawskich, żywieckich i śląskich ${ }^{127}$. Kwartowe odniesienia w melodyce zdają się słabnąć w kierunku zachodniej części łuku karpackiego ${ }^{128}$. W zachowanych u Karpatorusinów ze-

122 Przykładem mogą być tu zalotne zawołania pasterskie kobiet z Podhala tzw. wyskania, ujkania Rusinów z Osturni lub nieco bardziej rozbudowane melodycznie męskie ehokania Hucułów (o strukturach melodycznych sygnałów trembit) oraz nawoływania dziecięce wykonywane na pastwisku tzw. helokania z Beskidu Śląskiego z przykładowym tekstem: Helo, helo, Zuzanko, jako ci się pasie?, Helo, heloooo...

123 Za przykład można podać sygnały wygrywane na trembitach huculskich: J. Cząstka-Kłapyta, Kolędowanie na Huculszczyźnie, s. 358.

124 Farszeroci mieszkają przede wszystkim w Albanii. Do Rumunii przesiedlona została część Arumunów z Grecji i Macedonii. Jeśli znaleźli się między nimi jacyś Farszeroci to jest to grupa nieliczna, która swoje tradycje muzyczne przyniosła z terenu pogranicza Grecji i Albanii.

${ }^{125}$ Kwestie tą przeanalizowała gruntownie na przykładzie tradycji Łemków B. Tarasiewicz; Wesele Łemkowskie, s. 222, a na przykładzie analizy łemkowskich pieśni pasterskich Janusz Mroczek; Ze studiów nad melodiami temkowskich pieśni, s. 51-63. Przeanalizowałam ten problem studiując dostępne w sieci internetowej śpiewy arumuńskich Farszerotów oraz zbiór pieśni Arumunów: I. Caranica, 130 Melodii Populare. Niemal każda melodia zawiera tam frazy budowane w obrębie terachordów, skoki kwartowe, skłonności do descendentalnych zwrotów melodycznych np.: s. 13, 14, 15, 17, 18, 25, 26, 30, 33, 34, 35, $39,41,43,48,51,52,53,54,55,56$ itd. Kwestie tą badałam także w trakcie wieloletnich studiów etnomuzycznych nad pieśniami Osturnian, Rusinów z Małych Pienin, górali pienińskich oraz Hucułów.

${ }^{126}$ Goga, https://www.youtube.com/watch?v=6EWVFonKmZk [dostęp: 16.07.2021].

127 Pieśni z Orawy, s. 77 (nr. pieśni: 64, 74, 81, 91).

${ }^{128}$ Kwestia ta wymaga jeszcze dogłębnego przeanalizowania źródeł (zapisy melodii pasterskich). 
społowych śpiewach (heterofonii wariacyjnej) występują odległości dysonansowe i interwałów prostych jak: oktawy, tercje, seksty, sekundy i równoległe kwarty. Gdyby przeprowadzić eksperyment i z niektórych pieśni Faszerotów wyciągnąć główną linię melodyczną i zaprezentować ją w sposób monofoniczny, to uzyskalibyśmy struktury melodyczne bardzo zbliżone do najstarszych huculskich form spiwankowych albo melodii wygrywanych na fłojerze, także pod względem melizmatycznej stylistyki wykonawczej, która zaciera wyraziste kontury melodii. Jest to także dowód na istnienie mocno zakorzenionej w kulturze pasterskiej symbiozy muzyki wokalnej z instrumentalną.

\section{WIELOGŁOS KARPACKI}

Szukając analogii bałkańsko-karpackich nie można pominąć faktu wszechobecnego wpływu klasycznej polifonii europejskiej (połączenie monodii Bliskiego Wschodu i starożytnej polifonii europejskiej), której największy rozkwit rozpoczął się od XV wieku i zaczął przenikać przypuszczalnie na przełomie XVIII i XIX wieku do ludowej muzyki Karpat (śpiew w równoległych tercjach, sekstach, oktawach, struktury trójdźwiękowe, rozszerzenie skali, kończenie śpiewu na unisonie, harmonika funkcyjna) ${ }^{129}$. Takie cechy posiadają też śpiewy z Beskidu Śląskiego, Żywieckiego, Niskiego (kiedyś u Łemków). Na Słowacji formy ludowej wielogłosowości spotykane są na Orawie, Liptowie i Spiszu i jak po północnej stronie Tatr opierają się głównie na tercjach, rzadziej kwartach i kwintach, przy unisonowym zaczęciu i zakończeniu $^{130}$. Włodzimierz Kotoński zauważa, że „Muzyka góralska w jej obecnej postaci, z wysoko rozwiniętą wielogłosowością wokalną, „instrumentacją” i śmiałą harmoniką jest właściwie bardzo młoda ${ }^{131}$ " i może wiązać się z wpływami wojskowymi i od południa (ze Słowacji) ${ }^{132}$. Przyrodzoną, pierwotną formą wielogłosu karpackiego nie rządziły jednak prawa harmoniki funkcyjnej. Występuje on w regionach: Pienin, Podhala, Orawy i częściowo Zamagurza Spiskiego ${ }^{133}$ oraz po południowej stronie Gorców. Karpaty stanowią więc strefę przejściową między monodią, heterofonią i wielogłosem ${ }^{134}$. Wśród społeczności karpackich nie znają przyrodzonych form wielogłosowych jak już wspominałam Huculi (Ukraina), a w Polsce - Górale Babiogórscy, Żywieccy i Śląscy. Najogólniej można wyróżnić dwa typy wielogłosu góralskiego; starszy, w którym współbrzmienia opierają się w znacznej mierze na interwałach równoległych kwart i kwit oraz typ młodszy z dominująca rolą ter-

129 P. Dahlig, Tradycyjny śpiew wielogłosowy w Polsce $w$ perspektywie etnomuzykologii, „Łódzkie Studia Etnograficzne" 2018, t. 57, s.11.

130 Z. Przerembski, Muzyka ludowa po obu stronach Tatr, s. 49.

131 W. Kotoński, Uwagi o muzyce ludowej Podhala, cz. I, „Muzyka” 1953, nr 5/6, s. 20.

132 J., M. Sobiescy, Diafonia w Pieninach, s. 345.

133 We wsiach południowego Zamagurza, w których zaznaczają się wpływy z Podhala i sąsiedniej Osturni: Rzepiska, Łapszanka, Jurgów, Łapsze Wyżnie: badania własne.

134 P. Dahlig, Tradycyjny śpiew wielogłosowy, s. 11, 15. 
cji ${ }^{135}$ (przykł. 10, 11). W kierunku południowym od Karpat Wschodnich, w muzyce ludowej Rumunii i Grecji, tylko poza grupami Aromanów praktyka śpiewu wielogłosowego nie jest znana. Śpiewy wielogłosowe wiążą się często z repertuarem wykonywanym z dużą swobodą wykonawczą ${ }^{136}$, „bo jak się śpiewa wolno, to trzeba śpiewać na głosy, żeby się rozlegało". Najogólniej rzecz biorąc śpiew górali karpackich charakteryzuje się wertykalnym, harmonicznym myśleniem, w którym dominuje dwu-, trzy- i rzadziej czterogłos łączący się z krzyżowaniem głosów, który znają też Farszeroci (przykł. 8). Krzyżowanie głosów wyróżnia przede wszystkim wielogłos pieniński, po części też podhalański ${ }^{137}$ i rusiński (np. Osturnia i wsie rusińskie pod Małymi Pieninami). W efekcie krzyżowania głosów melodia główna nie zawsze leży w głosie najwyższym, lecz kryje się w głosie dolnym lub w środkowym - w przypadku trójgłosu. Dlatego też, wykonawcy określają głos naddany w interwale tercji nad główną melodią za drugi, wtórujący. Zdarza się, że niektóre śpiewaczki, obdarzone pięknym wysokim głosem, dodają głos drugi w interwale oktawy w stosunku do głosu dolnego. Melodie pieśni zaczyna jeden śpiewak - przodownik, do którego dołącza się unisono reszta grupy śpiewaczej prowadząc melodię swobodnie w ten sposób, że poszczególne głosy krzyżują się między sobą ${ }^{138}$. W starej praktyce wielogłosowej górali pienińskich niektórzy badacze słyszeli średniowieczną technikę discantus ${ }^{139}$, czasem słychać „cienki głosik” nadbudowany nad dwugłosem, który tworzy strukturę znaną także z odległej Połtawszczyzny (Ukraina), a którą można odnosić również do trzynasto- i czternastowiecznej polifonii zachodnioeuropejskiej ${ }^{140}$. Zasięg występowania wielogłosu pienińskiego wykracza jednak poza region zamieszkiwany przez górali pienińskich i obejmuje miejscowości sąsiedniej grupy - górali gorczańskich, którzy zamieszkują najstarszą w założoną w Polsce na prawie wołoskim wieś Ochotnicę - rozległą wieś pastersko-rolniczą leżącą na zachodniej granicy etnicznego zasięgu osadnictwa wołoskiego.

\section{DYSKUSJA}

Odrębność kulturowa południowego, karpackiego regionu Polski, a także innych obszarów Karpat położonych w kierunku wschodnim, może być w dużym stopniu wynikiem zaszczepienia pewnych bałkańskich elementów tradycji muzycznych przez zrutenizowanych osadników wołoskich. Wyodrębnione w tym artykule, pewne dystynktywne cechy wiążące tradycję wokalną bałkańskich Arumunów i karpackich gó-

135 J., M. Sobiescy, Diafonia w Pieninach, s. 352.

${ }^{136}$ Ibidem, s. 11.

137 W. Kotoński, Uwagi o muzyce ludowej Podhala, cz. III (O twórczym sposobie wykonania), „Muzyka” 1957, nr. 11/12, s. 26-45.

138 J., M. Sobiescy, Diafonia w Pieninach, s. 349, 350.

139 Ibidem.

140 P. Dahlig, Tradycyjny śpiew wielogłosowy, s. 13. 
rali stworzyły pewien strukturalny potencjalny model stylistyki dawnych śpiewów wołoskich, który mógł zwłaszcza w okresie migracji wołoskich wpłynąć na ukształtowanie pewnej stylistycznej specyfiki integrującej kulturę muzyczną Karpat. Kluczowe staje się tu pytanie w jaki sposób mogło nastąpić przejście od wysoko wyspecjalizowanych bałkańskich technik wokalnych (dron) do monodii huculskiej, czy tak daleko odbiegającego od polifonii bałkańskiej wielogłosu karpackiego? $\mathrm{Hu}-$ culszczyzna jest pewnym paradoksem. Z jednej strony zachowała najwięcej podobieństw z bałkańskimi tradycjami muzycznymi, z drugiej zaś, tylko u Hucułów nie zdołał wytworzyć się śpiew na głosy, poza tym będącym pod wpływem cerkwi, który nie wniknął w tkankę tradycyjnych śpiewów obrzędowych. Można zaryzykować hipotezę, że brak tworzenia wielogłosu może być efektem samotniczego pasterskiego typu osadnictwa, rozproszonego w górskim terenie, jak na Huculszczyźnie, gdzie stanowi w skali całych Karpat pewien fenomen w stosunku do przeważającego, skupionego w dolinach osadnictwa typu rolniczo-pasterskiego. Być może zwarty typ osadnictwa sprzyjał tworzeniu i przetrwaniu śpiewów heterofonicznych, zespołowych, które wymagały istnienia profesjonalnych i wtajemniczonych śpiewaków, głównie płci męskiej. Był chętnie kultywowany, przyswajany przez ludność rolniczą, ponieważ, podobnie jak dziś był jednym z najważniejszych czynników wyrażania etnicznej tożsamości. Natomiast rozbite osadnictwo o charakterze pasterskim, występujące w odizolowanych grupach rodowych mogło generować częściej monofoniczne lub homofoniczne śpiewy. W takich rozbitych strukturach plemiennych trudniej było tworzyć skomplikowane struktury heterobrzmieniowe jak np. polifonia typu drone. Stąd z biegiem czasu, takie lub podobne formy polifoniczne z ich bogatą złożonością muzyczną mogły zanikać, a przetrwały z nich jedynie najbardziej wyraziste linie melodyczne oraz ich dystynktywne cechy morfologiczne. Dzięki temu mogła przetrwać na Huculszczyźnie wokalna i instrumentalna monodia, której pierwotnie towarzyszył burdon głosowy w formie pedału dźwiękowego w grze na fłojerze, na skrzypcach i jak ma to nadal miejsce w grze na rogach i trembitach. Wobec istniejących związków zachodzących między instrumentalną a wokalną praktyką wykonawczą, nie można wykluczyć hipotezy funkcjonowania kiedyś w wokalnej tradycji zwłaszcza Hucułów i innych Karpatorusinów i być może innych grup góralskich podobnych struktur brzmieniowych (z burdonami głosowymi) przetrwałych na gruncie instrumentalnym ${ }^{141}$, a nawet w strukturze muzyki np. Podhala, gdzie wyraźnie da się wyodrębnić trzy poziomy brzmieniowe, jak w polifonii drona: prym, czyli główną, ozdobną linię melodyczną, kontrapunktujący sekund i burdonujące struktury harmoniczne (bas). Samotnicze osadnictwo sprzyjać mogło też rozwojowi solowej i bardziej wyspecjalizowanej gry instrumentalnej. Istnieje prawdopodobieństwo, że właśnie tymi czynnikami można tłumaczyć m.in. fenomen huculskiego bogactwa form i technik instrumentalnych ${ }^{142}$. Trzeba też wziąć jeszcze pod uwagę, że niektóre etnosy wołsokie niekoniecznie musiały być nośnikami tylko i wyłącznie wielogłosowych form śpie-

141 S. Mierczyński, Muzyka Huculszczyzny, red. J. Stęszewski, Warszawa 1965.

142 I. Macijewski, Muzyczni instrumenty Huculiw, red. J. D. Kolesnyk, Winnycja 2012. 
wu. Najprawdopodobniej niektóre z nich znały też monodię instrumentalną (śpiew z towarzyszeniem instrumentalnym), tak jak ma to miejsce nadal u niektórych greckich grup aromańskich (np. Epir). Zatem można hipotetycznie założyć, że źródłem rozwiniętych technik polifonicznych, wielogłosowości jest nie tylko funkcjonowanie w przestrzeni gór sprzyjającej uwrażliwianiu na akustykę brzmienia, ale także potrzeba podtrzymania społecznych więzi grupowych, czego najlepszym dowodem może być wyspecjalizowana polifonia drona, którą przechowały zintegrowane pasterskie grupy Aromanów i być może kiedyś Karpatorusinów. Wysoki, zaawansowany poziom tych śpiewów był dodatkowym czynnikiem integrującym i wyróżniającym społeczność wołoską, stąd mógł być trudny do przejęcia przez nie integrujące się z tym etnosem społeczności rolnicze nie znające śpiewu polifonicznego, jego reguł, czy orientalnych skal ${ }^{143}$. To samo może dotyczyć gry na dudach/gajdach/kozie ${ }^{144} \mathrm{i}$ zapewne na innych instrumentach jak: trombity/trembity/bucium oraz wyspecjalizowanych form budowy tych instrumentów, na których początkowo znali się tylko zromanizowani, następnie zrutenizowani i w końcu spolonizowani pasterze wołoscy. Rozbijanie w trakcie kilkuset lat trwających migracji więzi grupowych, odchodzenie starszych generacji pasterzy mogło generować procesy kruszenia pierwotnych tradycji polifonicznych i przechodzenia do monodii, a także stopniowego zacierania melizmatyki na rzecz sylabicznego toku wypowiedzi słowno-muzycznej na korzyść rozwoju poziomu wykonawstwa instrumentalnego i zindywidualizowanych technik gry. Powyższe hipotezy potwierdzają założenia Piotra Dahliga: ,,proces przechodzenia od wielogłosu do monodii jest także procesem indywidualizacji jednostki w społeczeństwie, rozproszenia instynktownych więzi grupowych, będących zapewne wynikiem postępującej modernizacji. Heterofonia zaawansowana, świadoma (czasem z elementami kontrapunktu) na pograniczach etnicznych Polski jest własnością społeczności o silnych więzach społeczno-terytorialnych”. Badacz wnioskuje, że przy takim rozumowaniu można założyć, że zintegrowane społeczności mogą tworzyć więcej polifonii, a podzielone - przeboje jednostkowe. Dodatkowym czynnikiem konserwującym muzyczną tradycję Wołochów była, poza kulturą muzyczną izolacja geograficzna i wyznaniowa, która separowała od Wołochów inne społeczności. Niewątpliwie góry, duże przestrzenie leśne, czy mokradła, jak na Polesiu były przez wieki regionami zamkniętymi na obce wpływy, co sprzyjało zachowaniu reliktowych form kulturowych o starożytnej proweniencji m.in. polifonii typu drone. Idea przetrwania starożytnej europejskiej tradycji polifonii w regionach odizolowanych geograficznie nie jest niczym nowym w etnomuzykologii. Rozwinięty w Karpatach wielogłos mógł być więc efektem zderzenia różnych technik wokalnych: homofonii, monofonii, którą znała lud-

143 Pieśni obrzędowe rolniczych przodków dzisiejszych Ukraińców były wykonywane zespołowo w sposób homofoniczny i opierały się na skalach diatonicznych. Chromatyzacja była zdaniem badaczy na gruncie muzyki ukraińskiej zjawiskiem późniejszym wiązanym z wpływami wołoskimi, bądź innymi wpływami orientalnymi (Persów, Tatarów, Arabów) lub oboma tymi źródłami oddziaływania; F. Kołessa, Charakterystyka ukraińskiej muzyki ludowej, „Lud Słowiański” 1934, t. 3, s. 35, 37, 38.

144 A. Guta, From Ius Valachicum to the Vlach. Folkloric influences within Central Europe, „Balcanica Posnaniensia. Acta et studia” 2015, t. 22, nr 1, s. 72. 
ność rolnicza, polifonii heterowariacyjnej, której nosicielami byli karpaccy Rusini oraz bałkańskiej polifonii drona, czy też jej pewnych elementów składowych, których nośnikami były jednostki lub grupy wołoskie. Piotr Dahlig nie wyklucza tej możliwości tworzenia wielogłosu przez osadników wołoskich: „Jeśli nowości kulturowe wiążą się często z migracjami ludności, to również wędrowni pasterze wołoscy zdają się być w polskiej części Karpat tymi śpiewakami, którzy uprawiali i popularyzowali śpiew wielogłosowy (...). Kulturowo-środowiskowy aspekt wielogłosowości w karpackim przypadku polega moim zdaniem na tym, że śpiew wielogłosowy może być traktowany jako zebranie (synteza) w jedno, współrozbrzmiewanie w czasie i przestrzeni tych śpiewów, rozproszonych w przestrzeni, które podejmowali pasterze na sąsiednich wzgórzach. Ów składnik komunikacji był niezwykle istotny. W plenerowym śpiewie górskim zawierano cały przekaz ludzkiej ekspresji, nie tylko walor śpiewno-estetyczny; śpiewano „całego siebie”, a nie tylko słowa. Warto dodać, że śpiew w interwale sekundy w Bałkanach rozwinął się w intencji, by głos, o „szorstkiej" barwie, z efektem dudnienia, niósł się jak najdalej. Wielogłos zatem mógł powstać z wołania, a nie tylko z namysłu nad dźwiękiem" ${ }^{145}$, co zanim dotarło w Karpaty najprawdopodobniej rozpoczęło się już wcześniej na Bałkanach. W tym miejscu można dodać, że lepszą akustykę i komunikacyjną nośność mają śpiewy których struktura melodyczna zbliżona jest do zawołań pasterskich, które - jak wykazała analiza - wedle wszelkiego prawdopodobieństwa mogą stanowić reliktową formę po pierwotnych śpiewach wołoskich, które do dziś kończą się w podobny sposób. Descendentalnemu rozwojowi melodyki (Podhale, Pieniny) i ogólnie poszerzeniu ambitus melodii sprzyjać mogło praktykowane u Karpatorusinów (Bojków, Rusinów z Pienin i Spisza) naddawanie od góry tercji do głównej linii melodycznej opartej na tetrachordach (i nie tylko). Proces syntezowania różnych tradycji wokalno-instrumentalnych, technik wokalnych, mógł być wynikiem mieszania ludności pasterskiej pochodzenia romańskiego (jako nośnika bałkańskich form polifonicznych typu dron) i rolniczej wschodniosłowiańskiej (znającej monodię i heterofonię wariacyjną). Tak wymieszana ludność romańsko-wschodniosłowiańska (Ruska) była nośnikiem zakorzenionych w świadomości różnych wzorów muzykowania np. glissandowania, orientalnych skal, tetrachordalnej, pentachordalnej struktury frazowej i repetycyjnej i descendentalnej melodyki i rytmiki etc. Powstawanie różnych wariantów melodycznych i technik śpiewu mogły generować zlokalizowane nawet w ramach jednej wsi kolektywne grupy muzykujące, których więzi muzyczne uwarunkowane mogły być cechami przestrzeni geograficznej (rozległe wsie, przysiółki, grzbiety górskie dzielące wsie). Takie wyizolowane w pewien sposób grupy tworzyły i utrwalały własne muzyczne idiomy wykonawcze przez Constantina Brăiloiu określane „,wariacje kolektywne”146, które w pewnych okolicznościach łączyć się mogły z innymi, co tworzyło rozmaite bogactwa brzmieniowe. Za przykład można podać Osturnię ${ }^{147}$, w której można odnaleźć kilka

145 P. Dahlig, Tradycyjny śpiew wielogłosowy, s. 13.

146 C. Brăiloiu, Vita muzicală a unui sat, t. 4, Paris 1960, s. 82, 85.

147 Wieś ta należy do największych na Słowacji i ma 9 km długości. 
odmian tzw. melodycznych wariantów kolektywnych (tzw. brauckiej nuty ${ }^{148}$ ) utrwalonych ze względu na miejsce zamieszkania; w dolnej, środkowej lub górnej części wsi ${ }^{149}$. Dalszy rozwój mógł polegać na przejściu od heterofonii do bardziej harmonicznego myślenia, którego tworzeniu sprzyjał opadający kierunek linii melodycznej. Wskazywałoby to na wartą jeszcze dokładnego przeanalizowania tendencje historycznego rozwoju meliki wołoskiej, czyli poszerzania tendencji do descendentalności wraz z kierunkiem przemieszczania się tego etnosu od południa na wschód i następnie w kierunku zachodnim ze swoją kulminacją w Pieninach, Gorcach (pd. strona) i na Podhalu. Tendencja do budowania fraz o melodyce opadającej słabnie w miarę przesuwania się w kierunku zachodnim Karpat na korzyść melodyki typu „schwebe” (falującej). Proces tworzenia bardziej złożonych form wielogłosowych ułatwiało zapewne postępujące wraz nowymi pokoleniami oczyszczenie melodyki pieśniowej z melizmatów, które zacierały jej wyrazistość, co ułatwiło poza istniejącym w podświadomości myśleniem linearnym dodawanie innych głosów w różnych odległościach interwałowych. Odejście od melizmatyki i burdonowania głosem (Huculszczyzna), mogło zostać w pewnym momencie uznane za odcinanie się od praktyki, starej, wiązanej z odchodzącym pokoleniem starych pasterzy (wołoskich), aż w końcu odeszło w przeszłość wraz z zanikiem pasterstwa. Melizmatyka i styl melizmatyczny najprawdopodobniej nikły na skutek mieszania się z ludnością rolniczą. Cały dynamizm rozwojowy szedł po linii rozbudowy melodyki śpiewów (przez śpiew na głosy) i myślenia harmonicznego. Występujące w Karpatach współbrzmienia kwintowo-kwartowe, dysonansowe (Karpatorusini) ustępowały stopniowo miejsca tercjowo-sekstowym, odbieranym jako bardziej „miękkie”150. Czynnikiem wpływającym na odmienność techniki wielogłosu karpackiego od bałkańskiego mogła być także tradycja czysto wokalnych wielogłosowych śpiewów cerkiewnych i kościelnych, które były znane w Europie Środkowo-Wschodniej już we wczesnym średniowieczu ${ }^{151}$. Różne typowe dla średniowiecznej diafonii techniki śpiewania na głosy (np. równoległe kwinty, tercje) mogły być znane zasiedlającej znaczny obszar Karpat prawosławnej ludności wołoskiej (rusińskiej). Tradycja wielogłosowych śpiewów liturgicznych jak pisze Piotr Dahlig - sprzyjała praktykom zwiększania wolumenu głosu przez dwui trzygłos ${ }^{152}$. Zwłaszcza w regionie Pienin i Gorców (Ochotnica) ${ }^{153}$ przetrwała do dziś silna więź wielogłosu z pieśnią religijną bez towarzyszenia instrumentalnego organów ze względu na jej wolne tempo wykonania i rozluźnienie rygorów metrorytmicznych, analogicznie jak w śpiewach na wolnej przestrzeni. W stylistyce wykonawczej

148 die Braut (niem.) - narzeczona, panna młoda; J. Cząstka-Kłapyta, Autoklasyfikacja repertuaru muzycznego, s. 123-138.

149 J. Cząstka, Charakterystyka etnomuzyczna wsi Osturnia.

150 P. Dahlig, Tradycyjny śpiew wielogłosowy, s. 13.

151 Ibidem.

152 Ibidem, s. 12.

153 W Ochotnicy lokowanej w 1416 roku na prawie wołoskim z udziałem osadników wołoskich istniała cerkiew. Informacja pochodzi z badań wywiadowczych Wojciecha Muleta przechowywanych w archiwum muzeum na Studzionkach w Ochotnicy. Potwierdza to konsultacja z Grzegorzem Jaworem. 
tych religijnych śpiewów zwłaszcza w Grywałdzie, Hałuszowej i w Ochotnicy przetrwało wiele archaicznych cech, które można zawdzięczać długo utrzymującą się w lokalnych kościołach tradycją kultywowania wielogłosowych śpiewów religijnych a capella ${ }^{154}$. Z potrzebą śpiewania na głosy związany jest zakorzeniony w świadomości tego etnosu wrodzony i utrwalony pokoleniowo słuch polifoniczny (harmoniczny). Mówiąc o rozwoju wokalnej dialektyki wołoskiej nie można pominąć kolosalnego wpływu muzyki instrumentalnej, jej podłoża skalowego, technik gry (na rogach, trąbach naturalnych, piszczałkach bezotworowych, dudach, skrzypcach), które oddziaływały na sposób kształtowania melodyki pieśniowej, niekiedy jej złożoną fakturę głosową, co zostało potwierdzone badaniami ${ }^{155}$. Związek między głosem a instrumentem omawia Piotr Dahlig: ,Podobnie jak w popularnej grze na dwupiszczałkowym aulosie dopatrywano się źródeł wyobraźni wielogłosu w starożytności, tak praktyka dudziarska, powszechna od wieku XVI na ziemiach polskich, podpowiedziała zapewne śpiewakom ludowym najprostszy dwugłos - dźwięk stały niski z równoczesną melodią" ${ }^{156}$. Ten ścisły związek śpiewu z instrumentem, który mógł być kiedyś szerzej rozpowszechniony wśród wołoskich pasterzy przetrwał jeszcze w huculskiej tradycji i u Aromanów. U greckich Aromanów z Epiru, podobnie jak u Hucułów i w innych regionach Karpat melodie wygrywane na tym instrumencie są analogiczne do śpiewanych i posiadają ten sam charakter czyli: ambitus seksty, tetrachordalną i pentachordalną budowa fraz muzycznych, dominacje ruchu sekundowego, skoki kwartowe zwłaszcza w zakończeniach kadencyjnych, ornamenty dźwiękowe wypełniające te skoki i stały niski burdon pozostający w relacji kwarty z melodią główną ${ }^{157}$. Instrumenty muzyczne mogły więc niezależnie od etnicznych wpływów integrować wokalną stylistykę karpacką.

\section{WNIOSKI}

Podstawowym wyróżnikiem muzyki Aromanów-Wołochów jest tradycja wokalna kultywowana zespołowo głównie bez towarzyszenia instrumentalnego, bądź z jego udziałem w formie heterofonicznej. Śpiew wielogłosowy, monofoniczny (z instrumentem), homofoniczny to praktyki wokalne znane zarówno Aromanom, jak i spadkobiercom karpackich Wołochów. Podobnie w charakterze melodyki śpiewów u obu grup występują zarówno formy o charakterze deklamacyjnym z mniejszym lub większym udziałem melizmatyki, jak i z rozwiniętą meandrującą i descendentalną melodyką. Analiza wykazała, że głęboko zakorzenioną specyfiką tej kultury, świadczącą

154 J. Cząstka-Kłapyta, Czy religijny śpiew górali pienińskich i gorczańskich zostanie ocalony?, „Prace Pienińskie” 2015, t. 25, s. 201-215.

155 Ibidem, s. 14.

156 Ibidem, s. 13.

157 Vlach bagpipe ballads (Timoc and Epir regions), https://www.youtube.com/watch?v=AQcdUEx0NO4 [dostęp: 16.07.2021]. 
o jej (typowych dla migrantów) więziach grupowych jest wypracowana pokoleniowo skłonność do śpiewania na głosy świadcząca o mocno zakorzenionym w genach wołoskich słuchu harmonicznym. Podobnie można wysunąć hipotezę, że znane w Pieninach i na Podhalu krzyżowanie głosów stanowi relikt wokalnych praktyk wielogłosowych zapośredniczonych najprawdopodobniej od zrutenizowanych Wołochów. Z wielogłosowością wiążę się także kolejna przyrodzona cecha etnosu wołoskiego jaką jest niezwykła wrażliwość na akustykę brzmienia, co wynika z wielopokoleniowego kultywowania śpiewów na rozległych przestrzeniach górskich. Ściśle zhierarchizowany śpiew z podziałem na głosy ze swoimi zróżnicowaniami w perspektywie chronologicznej i diachroniczej można potraktować więc jako wyróżnik wołoskiej etniczności. Rozpowszechniona w wokalnej stylistyce aromańskiej technika drona, w Karpatach przetrwała na gruncie muzyki instrumentalnej ${ }^{158}$, i w szczątkowej bardzo formie w tradycji pieśniowej niektórych Karpatorusinów. Ogólnie rzecz biorąc karpacki wielogłos charakteryzuje - jak na Bałkanach - rozpoczynanie pieśni przez „lidera”, który potem ciągnie wybijającą się główną linię melodyczną realizowaną najczęściej w obsadzie dwu-czterogłosowej (wyjątkowo pięciogłosowej - Podhale) przy równoczesnym zespołowym towarzyszeniu pozostałych głosów bardziej wyczulonych na jakości brzmieniowe niż tworzenie linii melodycznej o wyraźnych konturach. Pod względem brzmieniowym, karpackie struktury wokalne (poza wspomnianymi już wyjątkami) są bardziej monolityczne w brzmieniu od bałkańskich, które tworzą osadzone tylko na linearnym myśleniu dwie, trzy lub cztery niezależne heterohomofoniczne struktury brzmieniowe. Warta przebadania jest także kwestia krzyżowania głosów, która znana jest nie tylko w Pieninach, u Karpatorusinów (Małe Pieniny), ale także u Farszerotów. Fakty te świadczą o tym, że nie można wykluczyć możliwości istnienia kiedyś na terenie Karpat podobnych do polifonii drona struktur polifonicznych, czyli złożonych z głównej melodii (lidera) i kontrapunktu lub heterofonicznych układów głosowych, którym towarzyszył dron w formie pedału (stała nuta) lub rytmicznych układów stałodźwiękowych. Ich pozostałością są podobne konstrukty melodyczne, współbrzmienia dysonansowe i burdony, repetycje dźwiękowe i glissandowania występujące zwłaszcza w heterofonicznych śpiewach karpackich Rusinów oraz w niektórych innych regionach Karpat.

Elementami konstruktywnymi melodyki wołoskiej są: tetrachordalna ${ }^{159}$ i pentachordalna budowa fraz i prymarne znaczenie kwarty w zwrotach inicjalnych, międzyfrazowych bądź finalnych - glisandowanie i pohukiwanie głosowe zbliżone do zawołań pasterskich. Charakterystyczne wydaje się także zawieszanie głosu, fermatowanie dźwięków kulminacyjnych wywołanych często przez skok do góry w inter-

158 Patrz przypis 39.

159 Tetrachordalna budowa fraz muzycznych na gruncie polskiej muzyki ludowej nie jest zjawiskiem znanym tylko z regionu karpackiego. Archaiczny tetrachord zawierają także stare pieśni obrzędowe $\mathrm{z}$ regionu Wielkopolski. Zapewne melodie trychordalne i tetrachordalne, obok pentatoniki anhemitonicznej zaliczane są do chronologicznie najstarszej warstwy muzycznego repertuaru ludowego: M. Sobieski, Oblicze tonalne polskiej muzyki ludowej, [w:] Polska muzyka ludowa i jej problemy. Wybór prac, red. L. Bielawski, Kraków 1973, s. 365. 
wale kwarty (też kwarty zwiększonej) zarówno w muzyce wokalnej i instrumentalnej. We współbrzmieniach międzygłosowych kluczowe dla rozpoznania archaizmów wołoskich są kwarty, kwinty, oktawy i dysonanse, oprócz tercji jako późniejszych wpływów tonalnych. Ponadto pieśni wołoskie budowane są najczęściej na 6 i 8 sylabowej strukturze wersu słownego ( 8 sylabowa występuje u Aromanów i Karpatorusinów). Melodie cechuje skłonność do wolnych temp, melodyka ograniczona do wariantowego powtarzania jednej, bądź kilku fraz muzyczno-tekstowych w stylu deklamacyjno-melizmatycznym (Aromanie, Karpatorusini), lub w stylu sylabicznym z domieszką melizmatów ze stosowaniem szeroko rozplanowanych fraz oddechowych i punktów przystankowych na granicach fraz muzycznych. W kształtowaniu meliki zaznacza się przewaga ruchu sekundowego, skoki tercji, kwarty, repetycje dźwiękowe będące echem starożytnych deklamacyjnych śpiewów stojących na pograniczu mowy i muzyki oraz szeroko zakrojone frazy oddechowe. Charakterystycznym wołoskim substratem są orientalne wąskozakresowe skale ,skala wołoska”, lidyzmy, plagalizmy - odniesienia subkwartowe od dźwięku centralnego zwłaszcza w zakończeniach kadencyjnych ${ }^{160}$, obniżenie III stopnia, bifurkacja IV stopnia, zmienne intonacje, burdony głosowe i instrumentalne, descendentalna budowa fraz muzycznych zwłaszcza w zakończeniach, descendentalna rytmika (też punktowana), swoboda metro-rytmiczna (rubato), dwumiar, rzadziej trójmiar i pięciomiar, melizmatyka złączona z tzw. melizmatycznym stylem śpiewu (glissandowanie), stosowanie krótkich oddechów rozczłonkowujących frazy muzyczno-słowne, pohukiwania głosowe; u Aromanów zachowane zarówno w melodyce pieśniowej jak i w formie zawołań pasterskich. Takie pohukiwania w formie dodatkowego zakończenia pieśni pasterskich były kiedyś znane także na Podhalu ${ }^{161}$. Zawołania bałkańskie i karpackie opierają się na glissandowo łączonych dźwiękach w ramach krótkich fraz melodycznych o częściowo lub nawet całkowicie niesprecyzowanej wysokości i rytmice i opadającej melodyce. Zwrot melodyczny zawiera kilka sylab lub krótki przekaz semantyczny, szczególnie cechujący zawołania mężczyzn (Podhale, Huculszczyzna, Beskid Śląski). Istotnym elementem jednoczącym okazała się deklamacyjna, a także descendentalna melodyka, zwłaszcza w zakończeniach fraz muzycznych zachowana na peryferiach etnicznego zasięgu osadnictwa wołoskiego (region Pienin, Gorców (Ochotnica) i pozostający pod wpływem tego ostatniego - region Podhala. Tworzeniu zwłaszcza na gruncie polskich Karpat sprzyjało też w okresie średniowiecza wielogłosowych śpiewów liturgicznych wraz z długo utrzymującą się tradycją ich praktykowania bez towarzyszenia organowego (kościoły, cerkwie). Tym m.in. można ewentualnie tłumaczyć wysoki stopień rozwoju techniki wielogłosowej u górali pienińskich, podhalańskich i częściowo orawskich oraz u Karpatorusinów (poza Hucułami), których

160 J. Kresanek i B. Bartok uważali że tego typu zwroty zakończeniowe są pochodzenia wołoskiego: J. Kresanek, Slovenská ludová pieseň so stanoviska hudobného, Bratislava 1951, s. 271; B. Bartok, Slovenské l'udové piesne, Bratislava 1970, s. 46.

${ }^{161}$ Z. Przerembski, O dawnej muzyce na Podhalu, [w:] Góry i góralszczyzna w dziejach i kulturze pogranicza polsko-slowackiego (Podhale, Spisz, Orawa, Górce, Pieniny), red. J. Gotkiewicz, Nowy Targ 2005, s. 85 . 
śpiew jednak bardziej bazuje na heterofonii wariacyjnej i wpływach klasycznej harmonii. Kolejną cechą wołoską jest wariabilność z reguły nie wielkiej ilości uwarunkowanych lokalnie wątków melodycznych o zabarwieniu orientalnym (lidyzmy, skala wołoska z sekundą zwiększoną itd.). Interesujące w tym kontekście są analizy struktury melodycznej pasterskich pieśni z Beskidu Śląskiego Aurelii Domaradzkiej-Barbier (2001). Badaczka analizując zbiory pieśni z lat 1939, 1984 i 1994 dowiodła zachowania w przeciągu ponad parędziesięciu lat pewnych stałych, ponadczasowych, obiegowych pięciodźwiękowych struktur melodycznych, umownie nazwanych - wyjściową komórką góralską. Wszystkie formuły melodyczne analizowanych pieśni - jak stwierdza Barbier - są jej wariantami, opartymi na skali wołoskiej, bądź wąskozakresowych skalach z kwartą zwiększoną. Pomimo rozszerzenia ambitus melodii tych pieśni z upływem czasu i wpływami systemu tonalnego, struktury te nie uległy zatar$\operatorname{ciu}^{162}$. Jest to więc kolejny dowód na możliwość przetrwania na gruncie karpackim w świadomości zrutenizowanych grup aromańskich (Wołochów) pewnych konstruktywnych struktur melodycznych nasycających swym orientalnym brzmieniem sporą część repertuaru karpackiego, na których do dziś opiera się wokalna tradycja bałkańskich Vlachów. Niezwykła odporność tych - można powiedzieć - wyjściowych „komórek wołoskich” wynika zapewne z obrzędowej funkcji muzyki pasterskiej i jej magiczno-rytualnego podłoża - nieustannie powtarzane w różnych kombinacjach wariantowych krótkie frazy muzyczno-słowne, tworzyły jakby zdynamizowane ekspresją dźwiękową formuły magiczne zaklinające dobytek przed złymi siłami oraz szczęście i powodzenie podczas wypasu.

Śladem wołoskim wydaje się być także dymorficzna autoklasyfikacja repertuaru pieśniowego wiązanego z chronologicznie najstarszą warstwą repertuaru pieśniowego (pasterskiego) ${ }^{163}$. Ten problem wymaga dopracowania w regionach Rumuni i Bałkanów ${ }^{164}$. Podjęte tu problemy wymagają dogłębniejszego przeanalizowania najlepiej we wszystkich regionach związanych $\mathrm{z}$ etnosem wołoskim, chociaż w wielu miejscach jak np. w Rumuni pierwotne wołoskie cechy mogły ulec zatarciu lub wyparciu przez późniejsze wpływy węgierskie, saskie, romskie. W rezultacie, okazuje się, że przy zachowaniu pewnych rdzennych cech, wołoska kultura muzyczna jest odmienna, zróżnicowana w różnych krajach i regionach karpackich. Kluczowa w transferze muzycznych tradycji wołoskich na grunt Karpat okazał się zrutenizowany żywioł wołoski. Etnos karpatorusiński okazuje się być najbardziej wyraźnym nośnikiem nie tylko elementu etnicznie wołoskiego, ale co z tym się wiąże także reliktowych elementów aromańskiej kultury muzycznej Bałkanów, której wpływy przyniesione za pośrednictwem zromanizowanych Rusinów zdołały przeniknąc także do muzyki innych etnograficznych grup góralskich. Tu duża rola przypadła Ochotnicy, oddziały-

162 A. Domaradzka-Barbier, Praktyka muzyczna górali śląskich, s. 51-64.

163 Kryteria takiej klasyfikacji wymagają przeprowadzenia wywiadów z ludnością aromańską w perspektywie wewnątrzkulturowej.

164 J. Stęszewski, Rzeczy, świadomość i nazwy w badaniach etnomuzykologicznych (na przykładzie polskiego folkloru), „Rocznik Historii Sztuki” 1974, t. 15. 
wującej przez migrację osadniczą na kulturę po południowym skłonie Gorców, czyli np. Waksmund, Klikuszowa, z których następnie szły dalsze kierunki oddziaływań aż pod same Tatry. Drugą równie ekspansywną wsią wołosko-rusińską pod Tatrami była Osturnia, która przechowała wiele archaicznych cech muzycznych, także repertuaru pieśniowego wspólnych regionowi Spisza i Podhala ${ }^{165}$. Można posunąć się więc do hipotetycznego założenia, że tradycja wokalna Pienin, Podhala, częściowo Spisza stoi w swoich najbardziej archaicznych przejawach na fundamencie rusińsko-wołoskim $^{166}$. Oddziaływanie zrutenizowanych bałkanizmów muzycznych zdaje się jednak słabnąć w miarę przesuwania się śladem migracji wołoskiej w kierunku zachodnim, co wynika najprawdopodobniej z wcześniej i szybciej następujących tam procesów akulturacyjnych niż np. na Podhalu i w Pieninach oraz etnicznego zasięgu kolonizacji wołoskiej (przypis 4). Jeżeli do tych wniosków jeszcze dodać jednak złożone problemowo kwestie pośredniczenia Wołochów w transmisji niektórych wątków melodyki pieśniowej ${ }^{167}$ oraz instrumentów muzycznych jak: dudy, dwojnica, fłojera, trembita $^{168}$, których występowanie pokrywa się ze szlakiem przemieszczania się tego etnosu, to otrzymamy jeszcze pełniejszy obraz związków między odległymi regionami Karpat i Bałkanów. Z kolei proces tworzenia nowych ,języków muzycznych” był skutkiem kruszenia, petryfikacji starszych mniej lub bardziej przetrwałych na gruncie karpackim bałkańskich elementów muzycznych np. drona, melizmatyki itp.) zarówno w formach wokalnych jak i instrumentalnych. Muzyka wołoska to symbol jedności społecznej ludzi będących kiedyś „,w drodze”. Górale nadal czują swoje korzenie wołoskie i nie wyobrażają sobie dziś święta bez towarzyszenia rodzimej muzyki ,z naszych stron”. Muzyka wołoska wyrosła na fundamencie tradycji pasterskiej i zostawiła najwyraźniejsze ślady na gruncie tej właśnie tradycji. Uważam, że żywioł ten, uczestniczył w dość dużym stopniu w transmisji elementów muzycznych na teren Karpat, co zwiększa tylko wartość tego obszaru jako regionu który zdołał zatrzymać starożytne (trackie, iliryjskie?) muzyczne relikty kulturowe wpisane w tradycję indoeuropejską. Wołoskie dziedzictwo muzyczne pomimo wielu elementów wspólnych ma dziś wielokulturowe oblicze, w którym Karpaty i nie wykluczone, że także Roztocze i Polesie odgrywają rolę najdalej na północ w Europie wysuniętych obszarów ze śladami muzycznego dziedzictwa Bałkanów.

165 Mam tu na myśli leżące po polskiej stronie Zamagurza spiskiego: Jurgów, Rzepiska i Łapszankę.

166 CD-DVD, Muzyka bez granic.

167 Problem zasięgu melodii podhalańskich analizował A. Chybiński znajdując także związki wołoskie: A.Chybiński, O źródlach i rozpowszechnieniu dwudziestu melodii ludowych na Skalnym Podhalu [w:] O polskiej muzyce ludowej, Warszawa 1961, s. 113-143; J. Cząstka-Kłapyta, Muzyka Osturni w kontekście wieloetniczności Spisza, „Prace Pienińskie” 2017, t. 17, s. 237-241.

168 J. Cząstka-Kłapyta, Muzyczna kultura pasterska, [w:] Pasterstwo w Karpatach. Tradycja i Wspótczesność, red. M. Kiereś, B. Rosiek i inni, Warszawa, 2013, s. 57-69. 


\section{ANEKSY}

\section{Fragment śpiewu 2 głosowego z Epiru (Grecja)}

J. Jordania, Who asked the first questions? The Origins of human choral singing, intelligence, language and speech, Tbilisi 2006, s. 15-108, 117.

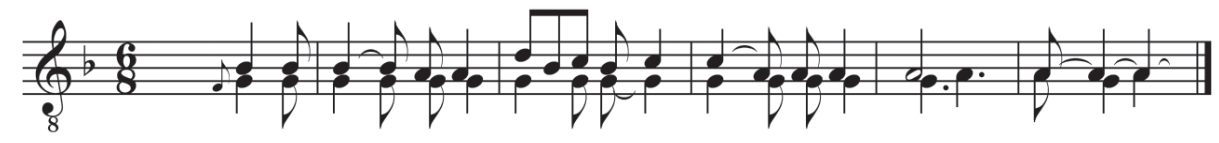

\section{Fragment trójgłosowego śpiewu Faszerotów z Rumuni}

M. Marcu, Folclor muzical Aromân, Bucureşti 1977, s. 206; J. Jordania, op. cit.

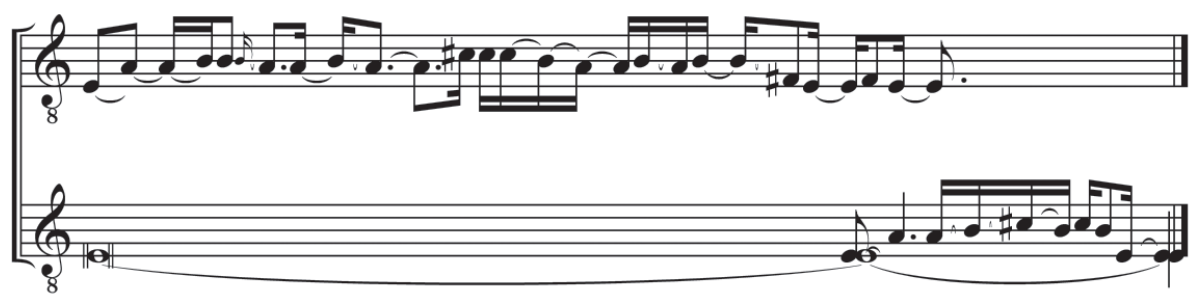

\section{Fragment dwugłosowego śpiewu z Pirinu (Bułgaria)}

N. Kaufman, Cîntece aromâneşti din Satul Dorkovo, Raionul Velingrad, „Revista de Etnografie şi Folclor” 1969, s. 123; J. Jordania, op. cit.

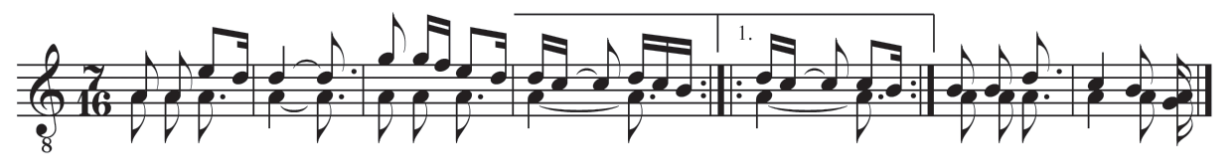

\section{Fragment trójgłosowego śpiewu z Pirynu (Bułgaria)}

N. Kaufman, op. cit., s. 205; J. Jordania, op, cit.

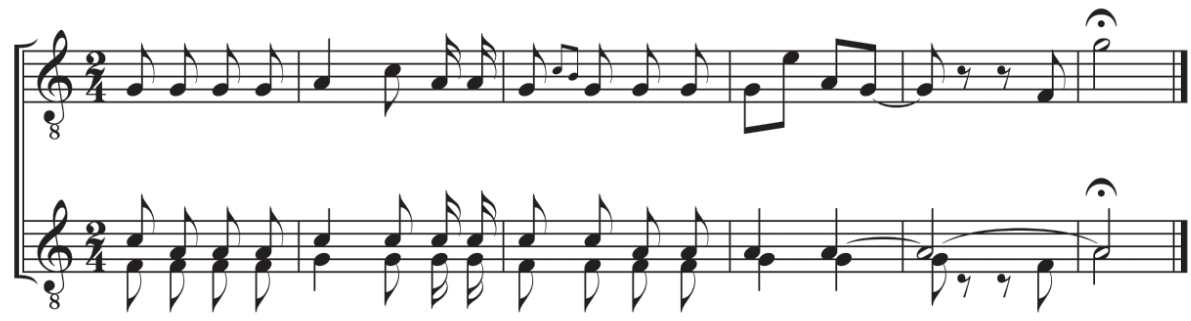


5.

\section{Mi lo somnul}

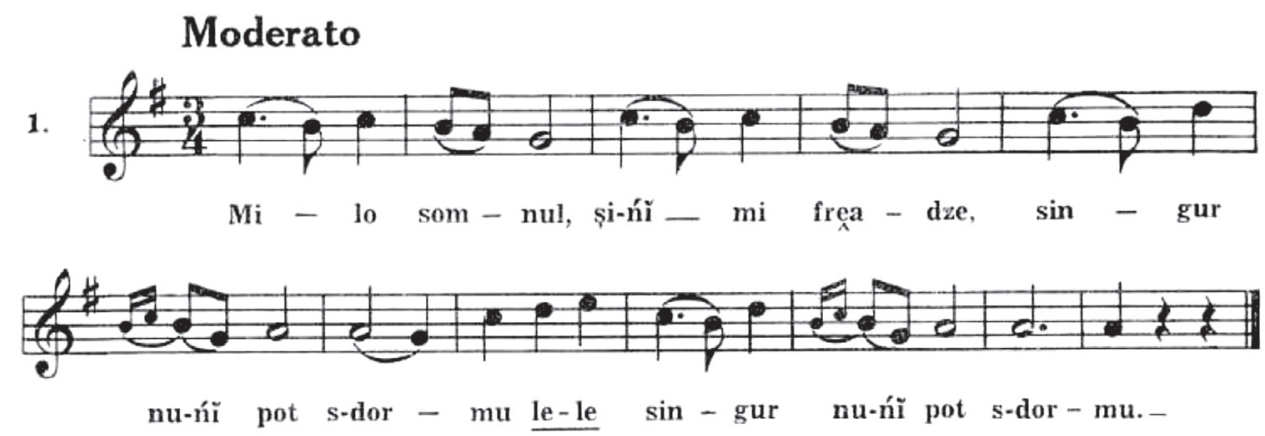

6.

\section{Morǐ tu lună}

Andantino

35.

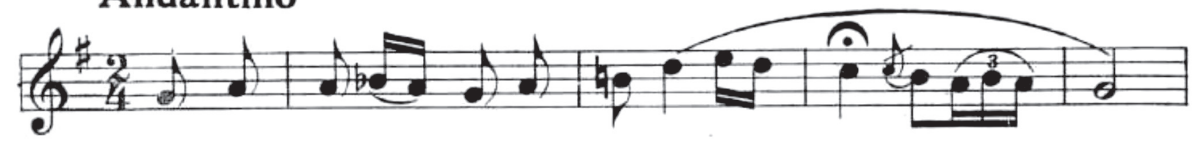

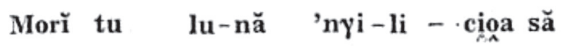

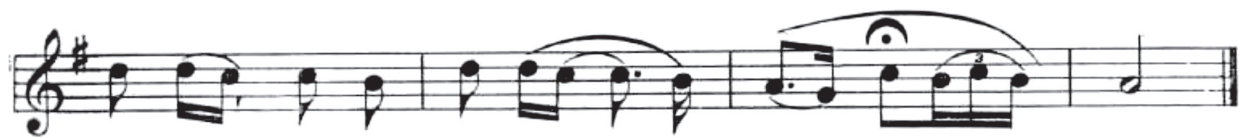
ţ'e-ști-a - naì - tă ș-di-păr — tọa să. 
7.

\section{Feată mușată}
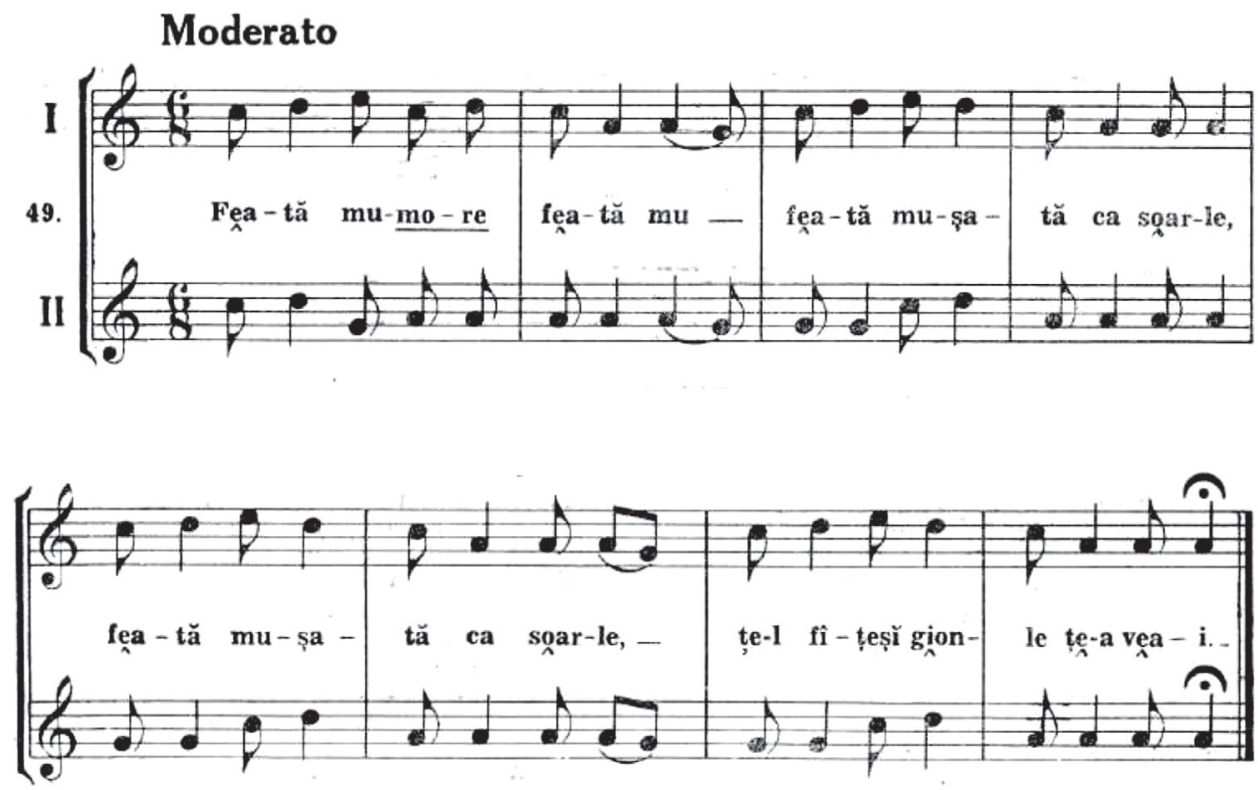

8.

\section{Ciamcu}

Se începe

majestos si se continuă

din ce in ce mai repede
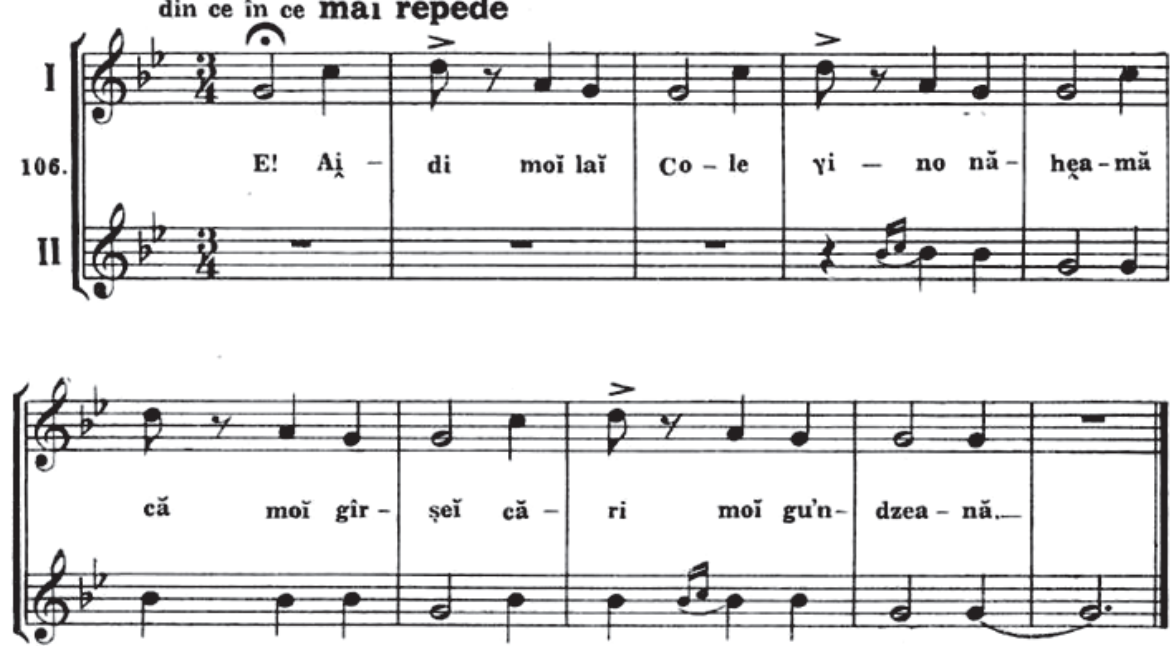


\section{Zawolania pasterskie z Podhala}

Z. Przerembski, O niektórych archaicznych cechach górali podhalańskich, „Muzyka” 1989, t. 34 , nr 4, s. 48

\section{Zawolanie meskie \\ Podhale ( Jesionkónka)}
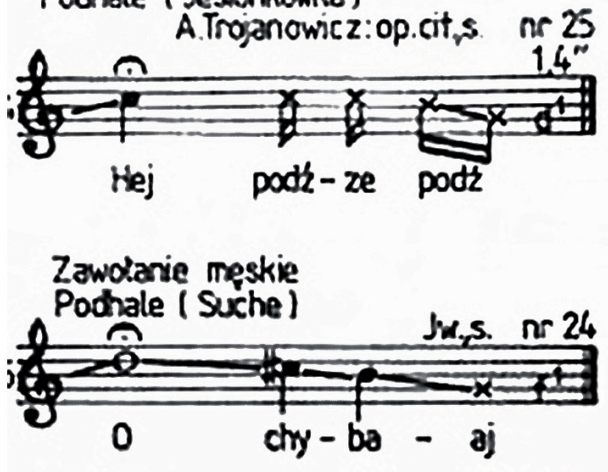

10. Wierchowa z Podhala

Muzyka Ludowa Polska, 1965, s. 258.

[Poco rubato] $\left(27^{\prime \prime}\right)[!=80]$

Podihale

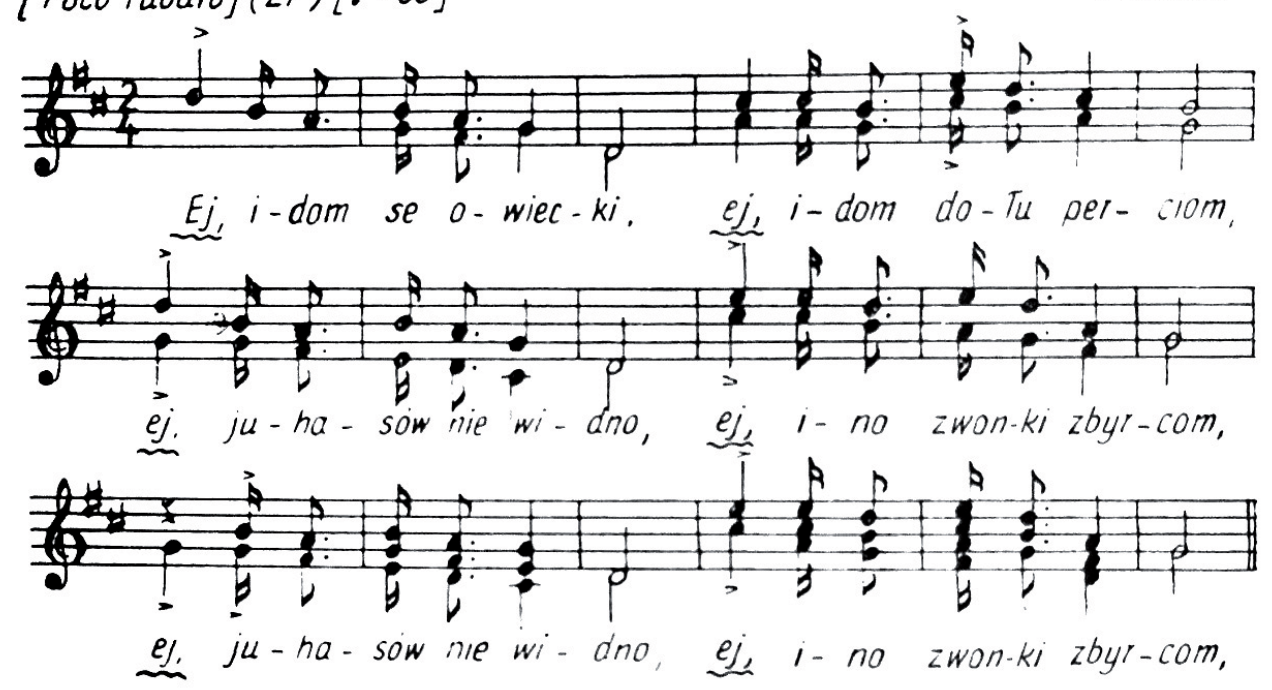




\section{Wielogłos pieniński (nagranie z 1951 roku)}

J., M. Sobiescy, Polska muzyka ludowa i jej problemy. Wybór prac, red. L. Bielawski, Kraków 1973, s. 347.

156 Tylmanowa pow. Nowy Targ 1951. Śpiewają dziewczęta i chłopcy. AFM T 671/10

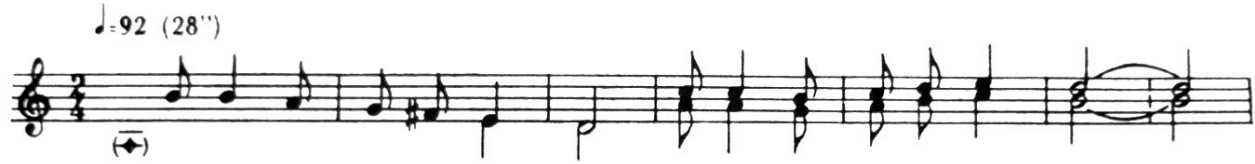

Ei pie-ron strze-lił sil - nie ej wy - so - kowdembi - ne

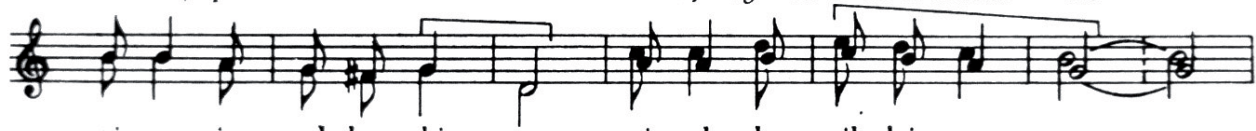

ej a jo pod dem-bi - ną ej ob - la - pil dzie-wcy - ne

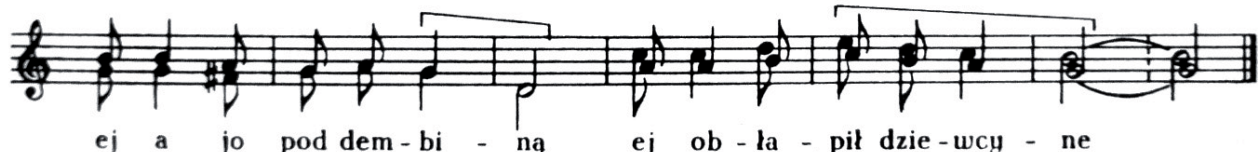

\section{Spiwanka na Rusalia (Zielone Świątki), Osturnia}

\section{J. Cząstka-Kłapyta, 2004 (badania własne).}
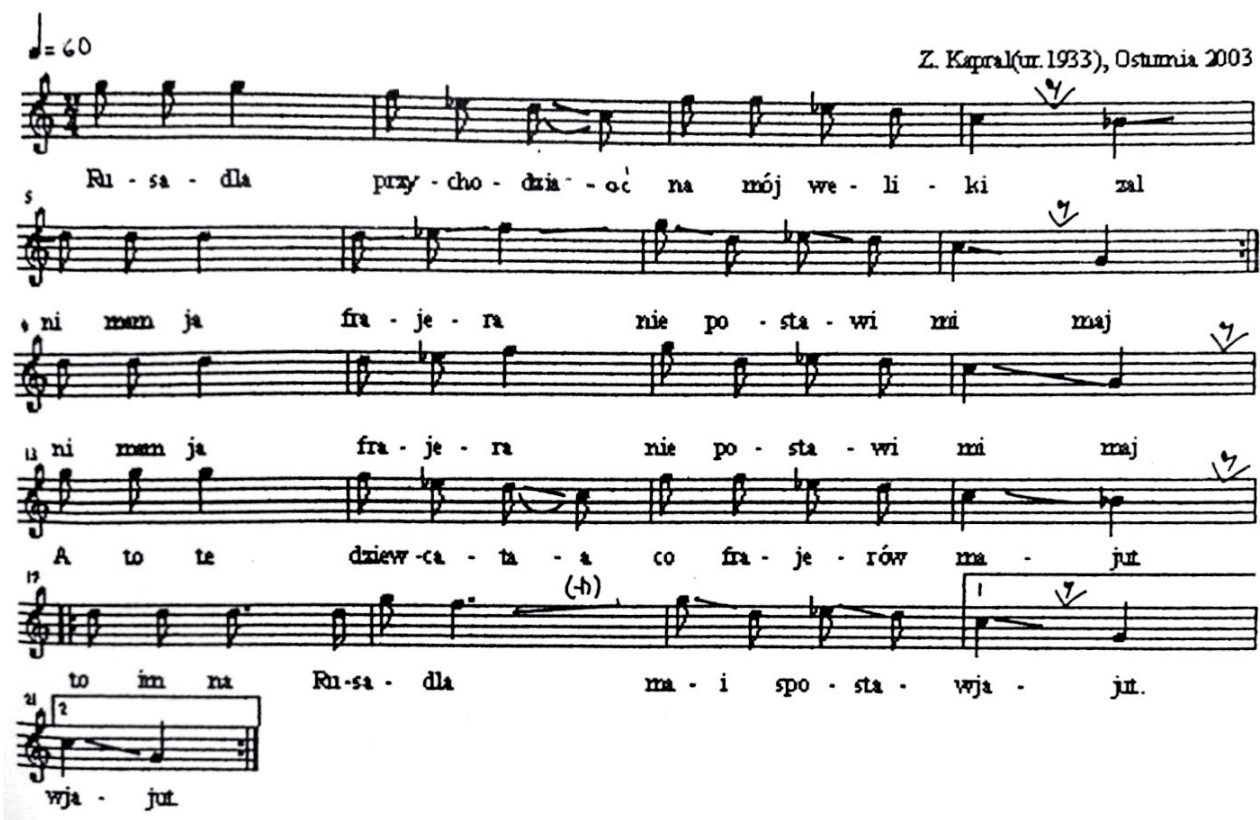


\section{3. juhaska Osturnia}

J. Cząstka-Kłapyta, 2004 (badania własne).
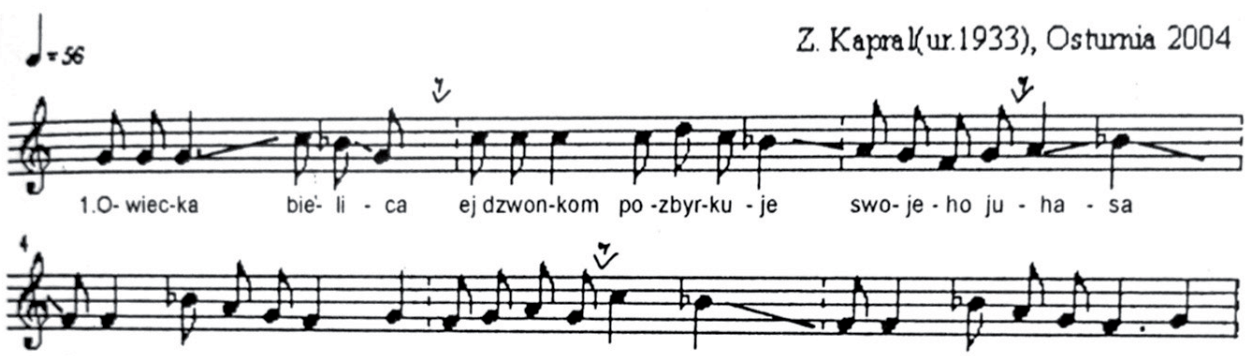

ej dzwon-kompo-zbyr-ku - je swo-je-ho ju-ha - sa ej sfre - ju po-ho-ku- je

\section{Litmanova - Majdany}

J. Cząstka-Kłapyta, 2018 (badania własne).

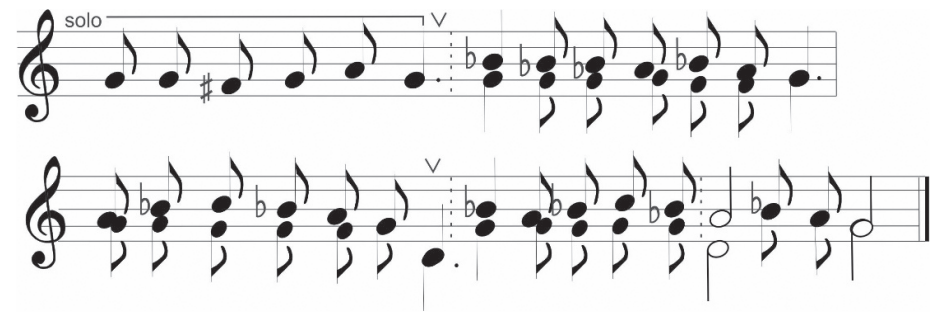

\section{Spiwanka pasterska z Lemkowszczyzny}

J. Mroczek, Ze studiów nad melodiami łemkowskich pieśni pasterskich, „, Materiały Budownictwa Ludowego" 1973, nr 17-18, s. 51-63.
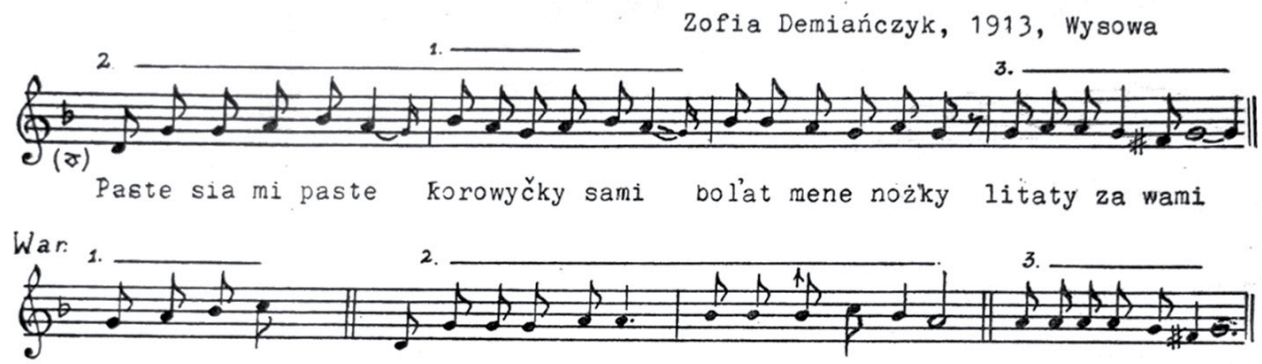


\section{BIBLIOGRAFIA}

Bartok B., Slovenské l'udové piesne, Bratislava 1970.

Bartok B., Hudobnowedny zbornik - casopis Slovenskej Akademie Vied., Bratislava 1954.

Bartok B., Das Ungarische Volkslied, Berlin und Leipzig 1924.

Bičanová K., Piesňovy repertoár Rusinov na hornym Spiši, „Slovenská hudba” 2000, t. 26, s. 291-304.

Bobrowska J., Polska folklorystyka muzyczna. Dzieje zbiorów i badań oraz charakterystyka cech stylistycznych polskiej muzyki ludowej, Katowice 2000.

Brabner J. H. F., The national encyclopcedia, t. 5, 1884, s. 99.

Brâiloiu C., Vita muzicală a unui sat, t. 4, Paris 1960.

Brăiloiu C., E. Comişel, T. Găluşcă-Cîrşmariu, Folclor din Dobrogea, Bucureşti 1978.

Burlasová S., Viachlasný spev na Horehroni, [w:] Interetnické vztahy vo folklóre karpatskej oblasti, red. V. Gašparíková, Bratislava 1980, s. 220.

Caranica I., 130 Melodii Populare Aromâneşti, Bucureşti 1937.

Chałupecky I., Dejiny Osturne, Kieżmark 2004.

Chybiński A., Karol Szymanowski a Podhale, „Wierchy” 1938, nr 16, s. 1-35.

Chybiński A., O źródtach i rozpowszechnieniu dwudziestu melodii ludowych na Skalnym Podhalu, [w:] O polskiej muzyce ludowej, Warszawa 1961, s. 113-143.

Czamańska I., Wołosi - strażnicy gór, [w:] Kalendarz 2014. Informacje pasterskie od owcy plus do Redyku Karpackiego 2013, Koniaków 2014, s. 17-33.

Cząstka J., Charakterystyka etnomuzyczna wsi Osturnia, dynamika przemian repertuaru muzycznego, praca magisterska pod kier. Jana Stęszewskiego, Instytut Muzykologii UJ, Kraków 2007.

Cząstka-Kłapyta J., Autoklasyfikacja repertuaru muzycznego na przykładzie rusińskiej wsi Osturnia (Zamagurze Spiskie), [w:] Huculi, Bojkowie, Łemkowie - tradycja i współczesność, red. J. CząstkaKłapyta, Kraków 2008, s. 123-138.

Cząstka-Kłapyta J., Muzyka Osturni w kontekście wieloetniczności Spisza, „Prace Pienińskie” 2007, t. 17, s. $237-241$.

Cząstka-Kłapyta J, Kolędowanie na Huculszczyźnie, red. A. Doboszewska, Kraków 2014.

Cząstka-Kłapyta J., Oral tradition. (Music), culture and nature: the European heritage of sheep farming and pastoral life, t. 3 (Research theme: Pastoral life. Research report for Poland by M. Maj, Lubaczów 2011; file://C:/Users/Admin/Downloads/PASTORAL_LIFE_NATIONAL_REPORT_ PL\%20(3).pdf [dostęp: 16.07.2021].

Cząstka-Kłapyta J., O uchwytnych zapożyczeniach i ich chronologii w tradycji muzycznej Hucułów, [w:] Huculszczyzna w badaniach młodych naukowców, red. M. Troll, A. Warchalska, Kraków 2011, s. $213-228$.

Cząstka-Kłapyta J., Wpływy wołoskie w folklorze muzycznym Karpat ze szczególnym uwzględnieniem Rusińskiej wsi Osturnia - przyczynek do rozważan, [w:] Woloskie dziedzictwo Karpat, Czeski Cieszyn 2007, s. 51-68.

Cząstka-Kłapyta J., Muzyka bez granic, [w:] CD-DVD, Pieniny - region pogranicza, Kraków 2017, s. $1-9$.

Cząstka-Kłapyta J., Muzyczna kultura pasterska, [w:] Pasterstwo w Karpatach. Tradycja i Wspótczesność, red. M. Kiereś, B. Rosiek, Warszawa, 2013, s. 57-69.

Cząstka-Kłapyta J., Folklor muzyczny, [w:] Kultura Ludowa Górali Pienińskich, red. U. Janicka-Krzywda, Kraków 2014, s. 507-530.

Cząstka-Kłapyta J., Czy religijny śpiew górali pienińskich i gorczańskich zostanie ocalony?, „Prace Pienińskie" 2015, t. 25, s. 201-215.

Cząstka-Kłapyta J., Funktion and genesis of "trombita" music instrument with special attencion to Huculschyna region, „Balcanica Poznaniensia. Acta et studia” 2016, t. 23, s. 187-196.

Dahlig P., Tradycyjny śpiew wielogłosowy $w$ Polsce $w$ perspektywie etnomuzykologii, „, Łódzkie Studia Etnograficzne" 2018, t. 57, s. 11-28. 
Domaradzka-Barbier A., Praktyka muzyczna górali ślaskich - analiza śpiewów beskidzkich i próba wyodrębnienia modelu struktury melodycznej, „Muzyka” 2001, nr 3, s. 51-64.

Elschek O., Stratigraphische Probleme der Volksmusik in den Karpaten und aufden Balkan, Bratislava 1981.

Elscheková A., Časová asymetria v slovenských l'udových piesňach, [w:] Interetnické vzt'ahy vo folklóre karpatskej oblasti, Bratislava 1980, s. 225-240.

Guta A., From Ius Valachicum to the Vlach. Folkloric influences within Central Europe, „Balcanica Posnaniensia. Acta et studia" 2015, t. 22, nr 1, s. 71-79.

Jordania J., Who asked the first questions? The Origins of human choral singing, intelligence, language and speech, Tbilisi 2006; http://citeseerx.ist.psu.edu/viewdoc/download?doi=10.1.1.470.3973\&rep= rep1\&type=pdf [dostęp: 16.07.2021].

Jawor G., La colonisation valaque sur les versants nord des Carpates pendant le Petit Âge Glaciaire (aux XVe et XVIe siècles), „Balcanica Posnaniensia. Acta et studia” 2018, t. 25, s. 251-268.

Jawor G., Kolonizacja wotoska na obszarach Wotynia w XV i XVI wieku. „Rocznik Lubelski” 2018, t. 44, s. $15-24$.

Kahl T., Multipart Singing among the Aromanians (Vlachs), [w:] European voices: multipart singing in the Balkans and the Mediterranean I, red. A. Ahmedaja, H. Gerlinde, Wien 2008, s. 267-284.

Katsanevakī A., I polyfōnia ton Vlachōntīs Pindou kai i farseriōtikī polyfōnia. Mia sygkritikī proseggisī,

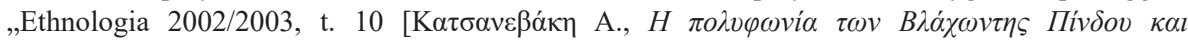

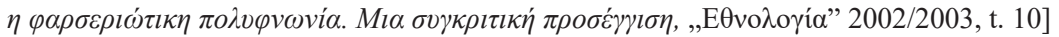

Kaufman N., Cîntece aromâneşti din Satul Dorkovo, Raionul Velingrad, „Revista de Etnografie şi Folclor” 1969, t. 14, nr 1, s. 69-75.

Kocój E, Dziedzictwo bez dziedziców? Religijne i materialne dziedzictwo kulturowe mniejszości pochodzenia woloskiego w Europie w kontekście interdyscyplinarnych badań, projektu (przyczynek do tematu), „Zarządzanie w Kulturze” 2015, t. 16, nr 2, s. 137-150.

Kłapyta P., Wołoskie osadnictwo w Karpatach w aspekcie historyczno-geograficznym, [w:] Kultura pasterska łuku Karpat i jej oddziaływanie na kulturę Babiogórców: materiały z konferencji naukowej zorganizowanej przez Babiogórskie Centrum Kultury w Zawoi z okazji 30. „,Babiogórskiej Jesieni”, 19 września 2014, red. U. Janicka-Krzywda, Kraków 2014, s. 9-26.

Kołessa F., Charakterystyka ukraińskiej muzyki ludowej, „Lud Słowiański” 1934, t. 3.

A. Kopoczek, Folklor muzyczny Beskidu Śląskiego, Katowice 1993.

Kotoński W., Uwagi o muzyce ludowej Podhala, cz. I, „Muzyka” 1953, nr 5/6, s. 3-25.

Kotoński W., Uwagi o muzyce ludowej Podhala, cz. III (O twórczym sposobie wykonania), „Muzyka” 1957, nr. 11/12, s. 26-46.

Kotoński W., Uwagi o muzyce Podhala, cz. IV (dokończenie), „Muzyka” 1954, nr. 6, s. 14-27.

Kresanek J., Slovenská ludová pieseň so stanoviska hudobného, Bratislava 1951.

Krzyżanowski J., Stownik Folkloru Polskiego, Warszawa 1965.

Lewandowska B., Folklor Muzyczny [w:] Kultura Ludowa Górali Orawskich, red. U. Janicka-Krzywda, Kraków 2011, s. 269-302.

Macijewski I., Muzyczni instrumenty Huculiw, red. J. D. Kolesnyk, Winnycja 2012.

Marcu M., Folclor muzical Aromân, Bucureşti 1977.

Marcu G., Un sistem identic de execuţie polifonică a cîntecelor populare, întîlnit la unele popoare din Peninsula Balcanică, „Revista de Etnografie şi Folclor” 1968, nr 13, s. 545-554.

Matvienko W., On some peculiarities of Ukrainian traditional polyphony, „Ukrainian Musicology” 1967, t. 2, s. $152-166$.

Mierczyński S., Muzyka Huculszczyzny, red. Jan Stęszewski, Kraków 1965.

Mroczek J., Ze studiów nad melodiami temkowskich pieśni pasterskich, „Materiały Budownictwa Ludowego" 1973, nr 17-18, s. 51-63.

Nowicka E., Nasz język rozumieja aniołowie. Arumuni we wspótczesnym świecie, Kraków 2011.

Nitsiakos V., Mantzos C., Negotiating culture: political uses of polyphonic folk songs in Greece and Albania, [w:] Greece and the Balkans: Identities, perceptions and cultural encounters since the Enlightenment, red. D. Tziovas, London 2003, s. 192-207. 


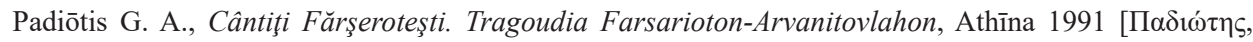

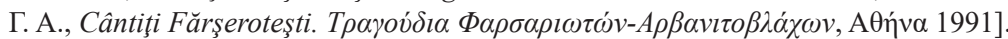

Pieśni z Orawy, red. B. Lewandowska, J. Kąś, Kraków 2007.

Przerembski Z., O dawnej muzyce na Podhalu, [w:] Góry i góralszczyzna w dziejach i kulturze pogranicza polsko-stowackiego (Podhale, Spisz, Orawa, Górce, Pieniny), red. J. Gotkiewicz, Nowy Targ 2005, s. 81-86.

Przerembski Z., Muzyka ludowa po obu stronach Tatr, podobieństwa, związki, różnice, kierunki oddziaływań, „Muzyka” 2018, z. 2, s. 43-58.

Przerembski Z., O niektórych archaicznych cechach górali podhalańskich, „Muzyka 1989, nr 4, s. 3149.

Sobiescy J., M., Diafonia w Pieninach, „Muzyka” 1952, nr 9, s. 15-29. Przedruk: Sobiescy J., M., Polska muzyka ludowa i jej problemy. Wybór prac, red. L. Bielawski, Kraków 1973, s. 344-360.

Sobieski M., Oblicze tonalne polskiej muzyki ludowej, [w:] Polska muzyka ludowa i jej problemy. Wybór prac, red. L. Bielawski, Kraków 1973, s. 361-382.

Stęszewski J., Muzyka ludowa, [w:] Etnografia Polski. Przemiany kultury ludowej, t. 2, Kraków 1974, s. $245-283$.

Stęszewski J., Rzeczy, świadomość i nazwy w badaniach etnomuzykologicznych (na przykładzie polskiego folkloru) „Rocznik Historii Sztuki” 1974, t. 15, s. 39-55.

Stockmann D., Stockmann E., Die Vokale Bordun-Mehrstimmigkeit in Südalbanien, [w:] Les Colloques de Wégimont, IV 1958-1960, „Ethnomusicologie” 1964, t. 3, s. 85-135.

Stockmann D., Fiedler W., Stockmann E., Albanische Volksmusik, t. 1 (Gesänge der Çamen. Veröffentlichungen des Instituts für deutsche Volkskunde), Berlin 1965, ss. 302.

Tarasiewicz B., Wesele Łemkowskie. Obrzęd i muzyka. Tradycja a wspótczesność, Legnica 2009.

\section{Strony internetowe:}

Bună-ți oara, picurare/Bună ziua, păcurare, https://www.youtube.com/watch?v=8RGT-e5PcnQ [dostęp: 16.07.2021].

Dzeana iu-ți vineai/Dealul pe care veneai, https://www.youtube.com/watch?v=e6KC11FrqKg [dostęp: 16.07.2021].

Goga" performed by Aristide Puiu \& Lealea Vanghele. Aromanian traditional folk song from the Farsherot community of Dobruja, https://www.youtube.com/watch?v=6EWVFonKmZk [dostęp: 16.07.2021].

Ia bagâț̦ stulia/Îmbracă-ți ia/Put your shirt, https://www.youtube.com/watch?v=iVU-DJCuVoY [dostęp: 16.07.2021].

International Reserch Center for Traditional Polyphony, http://polyphony.ge/en/category/world/centresof-polyphony/page/3/ [dostęp: 16.07.2021].

Majdany, Litmanova, https://www.youtube.com/watch?v=fyeAn4L7ttc [dostęp: 16.07.2021].

Old Bulgarian Wedding Folk Song - Moma se s Roda Proshtava, https://www.youtube.com/watch? $\mathrm{v}=$ W9fPINoFjoo [dostęp: 16.07.2021].

Muzyka bez Granic; https://www.youtube.com/watch?v=8V9ADJ2g9VY\&t=847s [dostęp; 16.07.2021].

Rufinka bolna legnala (Руфинка болна легнала), https://www.youtube.com/watch?v=9QR2MUtTkqA [dostęp: 16.07.2021].

Українська Автентична Музика, www.folk.org.ua [dostęp: 16.07.2021].

Vlach bagpipe ballads (Timoc and Epir regions), https://www.youtube.com/watch?v=AQcdUEx0NO4 [dostęp: 16.07.2021].

Vlach Song from Macedonia-Atanase Iorghitsa, https://www.youtube.com/watch?v=ey_XJe1_iIc [dostęp: 16.07.2021].

\section{Dyskografia:}

CD, Parea di Fârschirots di Nijopoli. Cântits Armânest, Bituli 2007.

CD-DVD, Muzyka bez granic. Pogranicze Pienin, opr. Justyna Cząstka-Kłapyta, Kraków 2017. 